\title{
BAZI TIBBİ BİTKİLERLE ZENGİNLEŞTİRİLMİŞ EKMEKLERİN DUYUSAL ÖZELLIKLERİ VE SATIN ALMA NIYYETİNE ETKISİ
}

\author{
Gözde Özdemir ${ }^{1}$, Dilek Dülger Altıner ${ }^{2 *}$, Yasemin Şahan ${ }^{3}$ \\ ${ }^{1}$ Kocaeli Üniversitesi, Sosyal Bilimler Enstitüsü, Turizm İşletmeciliği Anabilim Dalı, Turizm İşletmeciliği Yüksek \\ Lisans Programı, Kocaeli, Türkiye \\ ${ }^{2}$ Kocaeli Üniversitesi, Turizm Fakültesi, Gastronomi ve Mutfak Sanatları Bölümü, Kartepe, Kocaeli, Türkiye \\ ${ }^{3}$ Bursa Uludağ Üniversitesi, Ziraat Fakültesi, Gıda Mühendisliği Bölümü, Görükle, Bursa, Türkiye
}

Geliş / Received: 25.02.2021; Kabul / Accepted: 06.05.2021; Online bask1 / Published online: 14.05.2021

Özdemir, G., Dülger-Altıner, D., Şahan, Y. (2021). Bazı tıbbi bitkilerle zenginleştirilmiş ekmeklerin duyusal özellikleri ve satın alma niyetine etkisi. GIDA (2021) 46 (4) 767-784 doi: 10.15237/gida. GD21044.

Özdemir, G., Dülger-Alttner, D., Șahan, Y. (2021). The sensory properties of bread enriched with some medicinal plants and its effect on purchase intention. GIDA (2021) 46 (4) 767-784 doi: 10.15237/gida. GD21044.

ÖZ

Bu çalışmada tubbi bitki unları ile zenginleştirilmiş ekmek formülasyonlarının geliştirilmesi amaçlanmış ve buğday unu farklı oranlarda (\%1, 2 ve 3$)$ karahindiba unu ve civanperçemi unu ile ikame edilmiştir. Kontrol örneği, sadece buğday unu kullanılarak üretilmiştir. Zenginleştirilmiş ekmeklerin duyusal özellikleri (görünüş, lezzet/tat, koku, tekstür, ağızda bıraktığı his ve genel kabul edilebilirlik) tespit edilerek kontrol ekmeği ile karşılaştırllmış ve duyusal özelliklerin satın alma niyeti üzerindeki etkisi de tespit edilmiştir. Duyusal analiz değerlendirme sonuçlarına göre, kontrol örneğine en yakın özellikler gösteren ve en çok beğenilen \%1 karahindiba unu katkılı ekmek olmuștur. Bununla birlikte ekmek duyusal özelliklerinin satın alma niyeti üzerinde büyük oranda etkili olduğu sonucuna ulaşılmıştur. Araştırma sonucuna göre; sağlık yönünden faydaları bilinen bu tıbbi bitki unlarının gida sanayiinde kullanımının arttırlması ile yeni fonksiyonel ürün geliştirme çalışmalarında gıda katkısı olarak kullanılabileceği düşünülmektedir.

Anahtar kelimeler: Tıbbi bitki, karahindiba, civanperçemi, ekmek, gıda zenginleştirme, gıda katkıları

\section{THE SENSORY PROPERTIES OF BREAD ENRICHED WITH SOME MEDICINAL PLANTS AND ITS EFFECT ON PURCHASE INTENTION}

\begin{abstract}
The present study aimed to develop new bread formulations enriched with medicinal plant flours, and wheat flour was substituted with dandelion and yarrow plant flour in different ratios $(1,2$, and $3 \%$ ). The control sample was produced using only wheat flour. The sensory properties (appearance, flavor/taste, odor, texture, mouthfeel, general acceptability) of the enriched bread were determined and compared with the control bread, and the effect of the sensory properties of the bread on purchase intention was determined. According to the results of the sensory analysis, the bread with $1 \%$ dandelion flour was the most favored sample and showed the closest characteristics to the control sample. It was also concluded that the sensory properties of the bread had a great effect on purchase
\end{abstract}

\footnotetext{
* Yazışmalardan sorumlu yazar / Corresponding author

$\triangle$ dilek.dulgeraltiner@gmail.com,

(c) (+90) 2623533460

㚗 (+90) 2623534511
}

Gözde Özdemir; ORCID no: 0000-0001-6258-6260

Dilek Dülger Altıner; ORCID no: 0000-0002-7043-2883

Yasemin Şahan; ORCID no: 0000-0003-3457-251X 
intention. According to the results of the research, it is thought that these medicinal plant flours can be used as food additives for developing new functional products.

Keywords: Medicinal plant, dandelion, yarrow, bread, food fortification, food additives

\section{GİRIŞ}

Beslenme insanların yaşamını sürdürebilmesi için zorunlu bir faaliyettir (Ceyhun Sezgin et al., 2019). Gıdalar farklı mikro ve makro besin öğeleri içermesi, enerji verme, yapıyı düzenleme vb. özellikleri ile beslenmede önemlidir (Verhagen vd., 2021). Ekmek; gida tüketiminde yüksek enerji değerine sahip olması nedeniyle temel besin maddelerinden biri olarak kabul edilmektedir (Akgün, 2007; Bilgiçli, 2000). Ekmek, fiyatının uygun olmas1, doyurucu ve besleyici olmas1 nedeniyle sıklıkla tüketilmekte olup (Akgün, 2007; Durmuş, 2019; Göçmen, 2001; Yiğit ve Doğan, 2010), Türkiye'de günlük ekmek tüketimi kişi baş1 ortalama 284 g'dır (TMO, 2013).

Tibbi bitkiler, organlarından bir veya daha fazlası tedavi amaciyla veya ilaçların sentezinde öncü olarak kullanilabilen bitkiler olarak tanımlanmaktadır (Penso, 1980). Beslenmede kullanılan tıbbi bitkilerin, tedavi amacıyla kullanılan birçok fitokimyasal içerdiği (Brahma ve Narzary, 2015), ayrıca obezite ve kilo kontrolü için de kullanıldığı bilinmektedir (Jaradat vd., 2017). Tibbi ve aromatik bitkiler steroid, flavonoid, saponin, alkaloit, terpen ve fenolik bileşikleri içermekte olup, antimikrobiyal, antifungal, antialerjik, antidiyabetik, kardiyovasküler sistemi koruyucu, antioksidan, antikanser, antitiroid, antihistaminik, antimalaryal, antihelmintik, antienflamatuvar, antihipertansif, spazm çözücü ve ağr1 kesici gibi birçok özelliğe sahip oldukları bilinmektedir (Varlı vd., 2020 )

Karahindiba bitkisi (Taraxacum officinale L.) papatyagiller familyasina ait bir bitkidir (Demirezer vd., 2019). Türkiye'de 16's1 endemik olmak üzere 51 Karahindiba türü olduğu bilinmektedir (Özdemir vd., 2020). Karahindiba bitkisinin inulin, pektin, fenolik asit, asparagin, tanen, vitamin (A, B, C ve D), potasyum, lutein, karatenoid, demir, kalsiyum, magnezyum, fosfor, tiamin, saponin, sodyum, bakır, çinko, manganez, albümin, steroit, enzimler, flavonoidler, maden tuzları gibi çeşitli maddelerce zengin olduğu rapor edilmiştir (Gül, 2014; Özdemir vd., 2020; Turan,
2014). Buna ek olarak Karahindiba bitkisinin kök kısmı gaz, şişkinlik ve hazımsızlık gibi sindirim sorunlarında, karaciğer ve safra fonksiyonlarının düzenlenmesinde ve iştah açıcı olarak kullanilırken, toprak üstü kısımların idrar yolları tedavisinde kullanıldığı bilinmektedir (Demirezer vd., 2019).

Civanperçemi bitkisi (Acbillea millefolium L.) papatyagiller familyasina ait bir bitki olup (Demirezer vd., 2019; Howyzeh vd., 2019), yapılan çalışmalarda tanen, organik asitler, alkoloitler, flavonoidler, fosfor, potasyum, inülin, albümin, klorofil ve C vitamini gibi çeşitli maddeler içerdiği (Turan, 2014) ve antienflamatuar, antioksiyolitik, antimikrobiyal, antikanser (Edreva vd., 2019), antibakteriyel ve antifungal (Ahmadi-Dastgerdi vd., 2019) gibi birçok özelliği olduğu bildirilmiştir. Ayrıca, civanperçeminin yaraların, sindirim sorunlarının, cilt hastalıklarinin ve solunum yolu enfeksiyonlarının tedavisinde kullanıldığı da rapor edilmiştir (Howyzeh vd., 2019).

Gıda zenginleştirme işlemi, gıdada doğal olarak bulunan veya bulunmayan bileşenlerin, toplumda veya bir risk grubunda besin ögesi yetersizliğinin düzeltilmesi veya önlenmesi amaciyla gidalara daha fazla miktarda eklenmesi olarak ifade edilmektedir (Coşkun, 2012). Bu nedenle gidaya besin eklenmesinin tanınan bir besin eksikliği düzeltmek, işlem sürecinde kaybedilen besinleri eklemek, besin içeriği ile kalori içeriğini dengelemek, yeni ürünlerin besinsel yetersizliğini önlemek ve diğer program ve düzenlemelerle uyumlu hale getirmek için gerçekleştirilmesi gerektiği vurgulanmıştır (Boyacı, 2008; Kütük, 2010; Ranum, 2000). Günümüzde insanların sağlıklı beslenmeye yönelmesiyle gıdaların farklı teknikler ile besin içeriğinin zenginleştirildiği çalışmaların sayısının giderek arttığı görülmüsstür. Gıdaları zenginleştirmek için farklı fonksiyonel özellikler gösteren meyve, sebze ve bitki kaynaklarından yararlanılabilmektedir. Ekmekte yapılan zenginleştirme çalışmalarında, patates ve yulaf unu (Duran vd., 2004), sütçülük yan ürünleri 
(Demir vd., 2009), kimyon ve kimyon tohumu (Ahmad vd., 2018), yumurta kabuğu tozu (Adal, 2018), yeşil muz (Khoozani vd., 2020) ve maviyeşil alg (İlhan vd., 2020), kepekli tahıllar ve tohumlar (Benítez vd., 2018), buğday kepeği (Tiong vd., 2015), lupin unu (Tuluk, 2017), sarnıç ekstraktı (Mikulec vd., 2020), turunçgil albedosu (Demir ve Olcay, 2020), süt tozu (Burnaz ve Ertop, 2020) gibi çeşitli bileşenlerin kullanıldığ1 bildirilmiştir.

Bu çalışmada, sağlık açısından faydalı özellikleri olduğu bilinen iki farklı tıbbi bitkinin buğday ununa belli ikame oranlarında katılmasıyla, bitkilerde bulunan fitokimyasalların ve farklı fonksiyonel bileşenlerin ekmeğe kazandırılarak zenginleştirilmiş ekmek üretilmesi hedeflenmiştir. Üretilecek ekmeklere karahindiba ve civanperçemi bitki unlarının buğday ununa üç farklı ikame oraninda (\%1, \%2 ve \%3) kullanımının, duyusal kalite özelliklerine etkisinin belirlenmesi ve her bir ekmek için duyusal özelliklerinin, satın alma niyeti üzerindeki etkisinin tespit edilmesi amaçlanmıştır. Bu sayede, daha sağlıklı ekmeklerin üretilmesi, ekmek çeşitliliğine katk1 sağlanması ve tıbbi bitki kullanımının teşvik edilerek sürdürülebilir beslenme kapsamında katkı sağlanması da ön görülmüştür.

\section{MATERYAL VE METOT}

\section{Materyal}

$\mathrm{Bu}$ çalışmada, kurutulmuş olarak hazırlanan ve ambalajlı paketlerde satışa sunulan Karahindiba (Arifoğlu) ve Civanperçemi (Arifoğlu) bitkileri, buğday ununa farklı oranlarda ikame edilerek, zenginleştirilmiş ekmek üretmek amaciyla kullanılmıştır. Türk Gıda Kodeksi Gıdalarda Kullamlabilecek Bitkiler ve Bitkisel Preparatlar Tebliğ Ek-4 ve Ek-5'de yer alan "bitki listelerinde pozitif olarak yer alan bitkiler, bitki kısımları ve bitkisel preparatlar, varsa bu eklerde belirtilen koşullara uymak şartıyla piyasaya arz edilebilir ve gidalarda kullanılabilir" ifadesine göre çalışmamızda kullanılan bitkiler "pozitif" listede gösterilmiş olup, "kisımlarının ve/veya bitkisel preparatlarının, varsa kullanımla ilgili koşullara, kisttlamalara ve etiketleme gerekliliklerine uyulması şartı ile gıdalarda kullanılabileceği’" tebliğ maddesinde ifade edilmiştir (TGK, 2016). Satın alınan bitkiler, kahve ögütücü robotundan (Fakir - Hausgeräte) geçirilerek un haline getirilmiş ve 60 mesh çapl 1 elekten elenmiştir. Elde edilen un örnekleri, kullanilıncaya kadar, hava almayan kaplarda, buzdolabında $+4^{\circ} \mathrm{C}^{\prime}$ de 1 şıktan ve nemden korunacak şekilde saklanmıştır. Ekmek üretiminde kullanilacak hammaddelerden bitki materyalleri online olarak, ekmek formülasyonunda yer alan su (Erikli), maya (Pakmaya) ve tuz (Billur Tuz) yerel marketlerden, markalı ürünlerden satın alınmıştır.

\section{Ekmek Üretimi}

Çalışmada kullanılan ekmek formülasyonu, Akgün (2007) ve Pala (2012)'nin çalışmaları modifiye edilerek kullanılmıştır. Tıbbi bitkilerin ekmeklerde kullanım oranları, ön denemeler sonucu belirlenmiştir. Yapılan ön denemelerde, literatür bilgileri dahilinde ekmeklere $\% 4, \% 5$ ve $\% 6$ oranlarında bitki unları ilave edilerek deneme yapılmıştır. Ancak, ön deneme için üretilen ekmekler katılımcilar tarafindan acı bulunarak tercih edilmemiştir. $\mathrm{Bu}$ nedenle, ekmeğin zenginleştirilmesinde buğday ununa ikame olarak $\% 1, \% 2$ ve $\% 3$ oranlarında Karahindiba ve Civanperçemi unları eklenmiştir. Ayrıca sadece buğday unu kullanılarak kontrol ekmeği üretilmiştir. Ekmek formülasyonu ve kodları Çizelge 1'de, ekmek üretim modeli Şekil 1'de verilmiştir.

Çalışma kapsamında, direkt hamur metodu kullanılmıştır. Kullanılan ekmek üretim akım şeması, Ödeş (2018)'in çalışması baz alınarak yapılan ön çalışmalar sonucu oluşturulmuştur. Bu amaçla, ekmek üretiminde kullanılan tüm materyaller tek seferde karıștırılarak yoğurulmasıyla hamur elde edilmiștir. Elde edilen hamur, $40^{\circ} \mathrm{C}$ 'de 30 dakika boyunca kitle fermentasyonu (1. fermentasyon)'a bırakılmıştır. Fermentasyon sonucunda hamur tartılmış ve şekil verilerek pişirme kaplarına yerleştirilmiştir. Daha sonra hamur $40^{\circ} \mathrm{C}$ 'de 90 dakika boyunca parça fermantasyonuna (2. fermentasyon) bırakılmıştır. Fermentasyon sonunda hamur, $250^{\circ} \mathrm{C}$ 'de 15 dakika boyunca pişirilerek ekmekler elde edilmiștir. Fırından (Luxell marka) çıkan ekmekler, oda sıcaklığında soğumaya bırakılmıştır. 
Çizelge 1. Ekmek formülasyonu

Table 1. Bread formulation

\begin{tabular}{|c|c|c|c|c|c|c|c|}
\hline $\begin{array}{l}\text { Ürün Ad }{ }^{1} \\
\text { Product Name }\end{array}$ & $\begin{array}{l}\text { Ürün } \\
\text { Kodu } \\
\text { Product } \\
\text { Code }\end{array}$ & $\begin{array}{l}\text { Buğday Ununa } \\
\text { İkame Oranı } \\
\text { Substitution } \\
\text { Ratio for Wheat } \\
\text { Flour }\end{array}$ & $\begin{array}{l}\text { Un } \\
\text { Miktar1 } \\
(\mathrm{g})^{2} \\
\text { Flour } \\
\text { Amount }\end{array}$ & $\begin{array}{c}\text { Bitki Unu } \\
\text { Miktar1 (g) } \\
\text { Plant Flour } \\
\text { Amount }\end{array}$ & $\begin{array}{l}\text { Maya } \\
(\mathrm{g}) \\
\text { Yeast }\end{array}$ & $\begin{array}{l}\text { Tuz } \\
\text { (g) } \\
\text { Salt }\end{array}$ & $\begin{array}{c}\mathrm{Su} \\
(\mathrm{ml}) \\
\text { Water }\end{array}$ \\
\hline $\begin{array}{l}\text { Kontrol Ekmeği } \\
\text { Control bread }\end{array}$ & K & $\% 0$ & 300 & 0 & 6 & 4.5 & 200 \\
\hline Karahindiba unu & K1 & $\% 1$ & 297 & 3 & 6 & 4.5 & 201 \\
\hline katk1lı ekmek & K2 & $\% 2$ & 294 & 6 & 6 & 4.5 & 202 \\
\hline $\begin{array}{l}\text { Bread enriched } \\
\text { with dandelion flour }\end{array}$ & K3 & $\% 3$ & 291 & 9 & 6 & 4.5 & 203 \\
\hline Civanperçemi unu & C1 & $\% 1$ & 297 & 3 & 6 & 4.5 & 200 \\
\hline katkilı ekmek & $\mathrm{C} 2$ & $\% 2$ & 294 & 6 & 6 & 4.5 & 200 \\
\hline $\begin{array}{l}\text { Bread enriched } \\
\text { with yarrow flour }\end{array}$ & C3 & $\% 3$ & 291 & 9 & 6 & 4.5 & 202 \\
\hline
\end{tabular}

${ }^{1}$ Bileşenler $21 \pm 1^{\circ} \mathrm{C} ;{ }^{2} \% 14$ rutubet esasına göre

${ }^{1}$ Ingredients at $21 \pm 1{ }^{\circ} \mathrm{C},{ }^{2} 14 \%$ moisture basis

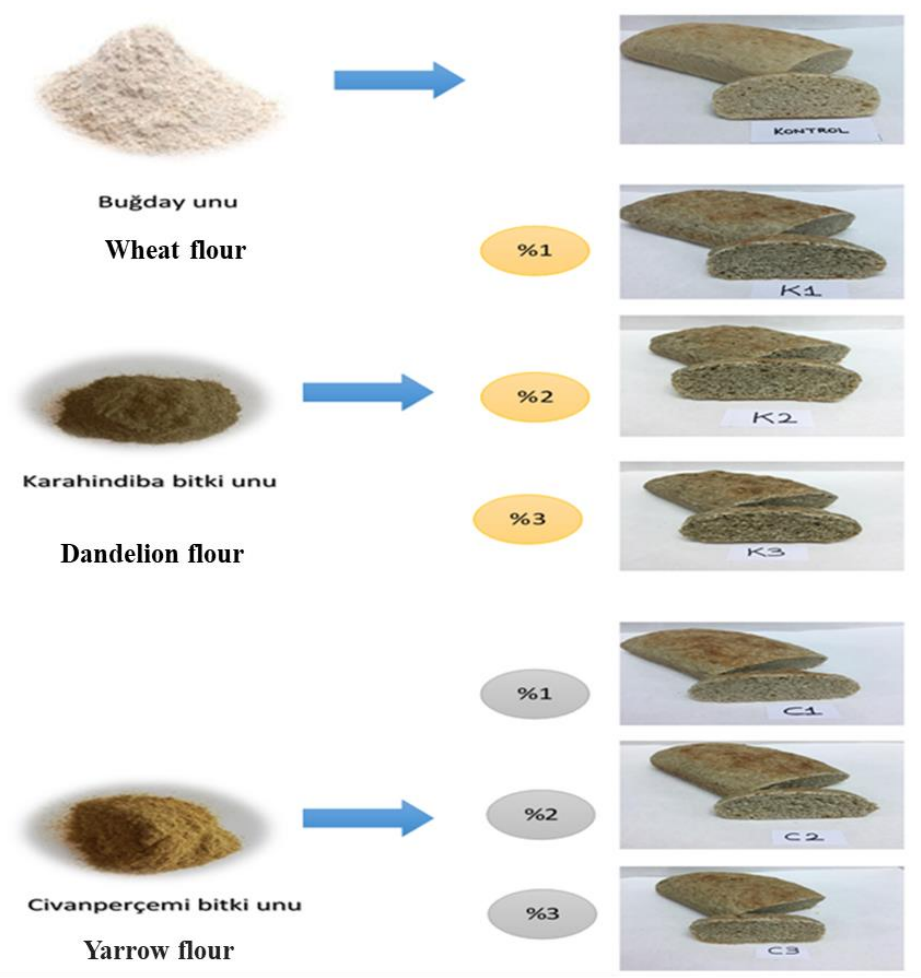

Şekil 1. Ekmek üretim modeli (K: tıbbi bitki içermeそ, sadece buğday unu; K1:\%1 karabindiba unu, K2: \%2 karabindiba unu, K3:\%3 karabindiba unu katkill ekmek; C1: \%1 civanperçemi unu, C2: \%2 civanperçemi unu, C3:\%3 civanpercemi unu katkill ekemek.)

Figure 1. Bread production model (K: without medicinal plant, only wheat flour; K1:1\% dandelion flour, K2: 2\% dandelion flour, K3: 3\% dandelion flour-enriched bread; C1: 1\% yarrow flour, C2: 2\% yarrow flour, C3: 3\% yarrow flour-enriched bread) 


\begin{abstract}
Metot
Duyusal Analiz

Duyusal analiz paneli, 21 Kasım - 29 Kasım 2020 tarihleri arasında, Mersin ili Erdemli İlçesinde, Kumkuyu Limani'nda bulunan bir kafede 19-75 yaş aralığındaki (83 kişi - 34 Kadın / 49 Erkek) tüketicilerin katılımı ile gerçekleştirilmiştir. Duyusal analizde farklilık testleri için 10-20 panelist yeterli kabul edilirken, tüketici testlerinde en az 80 kişi olması gerekmektedir (Onoğlu ve Elmac1, 2019). Bu nedenle çalışmamız tüketici testi olarak kabul edilmektedir.
\end{abstract}

Duyusal analiz formunda; tüm duyusal değerlendirmeler, ekmeklerdeki duyusal kalite kriterlerini içeren; Dursun (2006) ve Pala (2012)'nın çalışmaları incelenerek, konu ile ilgili yapılmış uluslararası çalışmalar (Giboreau vd. 2007; Annett vd. 2007; Elía 2011; VindrasFouillet vd. 2014; Ho 2015; Shrivastava vd. 2018; Robles-Ramírez vd. 2020) dikkate alınarak tarafımızca geliştirilmiş ve ön denemeler ve uzman görüssleri sonucunda son haline getirilmiştir. Literatür araştırması sonucunda, çalışma konusuna özgü olarak modifiye edilmesiyle hazırlanmış tadım formu üzerinde, 15 hedonik skalası (5 Puan: Çok iyi, 4 Puan: iyi, 3 Puan: Kabul edilebilir, 2 Puan: Yeterli değil, 1 Puan: Kötü) kullanılarak ekmeklerin duyusal analizi yapılmıştır. Panelistler, birbirinden etkilenmeyecek şekilde, aydınlık ve dış etkenlere kapalı olan ortamda puan vermişlerdir. Duyusal analiz, uluslararası standartlara (1087 1990; ISO 8586 1993; ISO 8589 2007) uygun bir duyusal panel yapılarak gerçekleştirilmiştir.

Duyusal analiz formu üç bölümden oluşmakta olup, ilk bölümde ekmek örneklerine ait duyusal özelliklere, ikinci bölümde ekmek üretiminde kullanılan katkı tipi, maya tipi ve un tipi hakkında tüketici tahminlerine, üçüncü bölümde ise puan verilen ekmek duyusal özelliklerinin tüketici satın alma niyeti üzerindeki etkisi ölçülmüştür. Panelistler, birbirinden etkilenmeyecek şekilde, aydınlık ve diş etkenlere kapalı olan ortamda puan vermişlerdir. Ekmekler; hacim, kabuk rengi, iç rengi, gözenek yapısı, şekil simetrisi, genel lezzet yoğunluğu, genel aroma yoğunluğu, genel koku yoğunluğu, çiğnenebilirlik, sertlik, yapışkanlık, ufalanma, ağızda bıraktığ1 his ve genel kabul edilebilirlik olmak üzere on dört (14) özellik bakımından değerlendirilmiştir. Duyusal analiz formunun ikinci bölümünde, panelistlere, ekmek üretimleri sırasında kullanılan katkı tipi (meyve, sebze, bitki, baklagil, diğer), maya tipi (kuru maya, yaş maya, ekşi maya, nohut mayas1, diğer) ve un tipini (buğday unu, tam buğday unu, çavdar unu, yulaf unu, diğer) tahminlerini işaretlemeleri istenmiştir. Duyusal analiz formunun üçüncü bölümünde ise, panelisterin, ekmekleri satın alma niyetini ölçmek amaciyla Shiv vd. (1997) tarafından geliştirilmiş ifade (satın alma niyeti) gösterilmiş, 1-5 hedonik skalas1 (5 puan: Kesinlikle kat1lyorum, 4 Puan: Katıllyorum, 3 Puan: Ne kat1liyorum ne de katilmiyorum, 2 Puan: Katılmıyorum, 1 Puan: Kesinlikle katılmıyorum) verilen puanlara göre, tüketicilerin duyusal panelde değerlendirdiği ekmeklerin duyusal özeliklerinin tüketici satın alma niyetine etkisi ölçülmüştür. Duyusal analizler için Kocaeli Üniversite'sinden 19/11/2020 tarihli E-79955 sayılı Etik Kurul Onayı alınmıştır.

\section{İstatiksel Analiz}

Duyusal analiz formunun ilk bölümünde, verilerin değerlendirilmesinde JMP IN 7.0.0 (Statistical Discovery from SAS 2007. Institue Inc.) program1 ile varyans analizi kullanılarak değerlendirilmiştir. Elde edilen ortalama değerler arasındaki istatistiki farklı grupların belirlenmesinde $P<0.05$ olasilik düzeyinde "LSD (Least Significant Difference) testi" kullanılmıştır. 3 tekerrürlü olarak tesadüf parselleri deneme desenine göre yürütülmüştür. Duyusal analiz formunun diğer bölümlerinde SPSS 23.0 istatistik programı kullanılmıştır. Elde edilen verilere tanımlayıcı (yüzde ve frekans) analizi ve doğrusal regresyon analizi uygulanmıştır.

\section{BULGULAR VE TARTIŞMA}

\section{Katılımcıların Özellikleri ve Duyusal Analiz} Tahminleri

Araştırmaya dahil edilen katılımcıların \%41'ini (34 kişi) kadınlar, \%59'unu (49 kişi) ise erkekler oluşturmaktadır. Katılımcıların \%49,4'ünü (41 kişi) "18-25 yaş aralığı" oluştururken \%45,4'ünün (38 kişi) lisans mezunu olduğu belirlenmiştir. Gelir düzeyi açısından incelendiğinde $\% 32,5$ 'inin (27 kişi) "1500 ve altı" gelir grubunda yer alırken 
\%31,3’ünün (26 kişi) “4500 ve üzeri” gelir grubunda yer aldığ1 görülmektedir.

Duyusal analiz paneline katılanlarin ekmek tüketim alışkanlıkları Çizelge 2'de verilmiştir. Sonuçlar incelendiğinde katılımcıların \%32,5’inin (27 kişi) günde 1-2 dilim, \%43,4'ünün (36 kişi) günde 3-4 dilim, \%18,1'inin (15 kişi) günde 5-6 dilim ve \%6'sının (5 kişi) günde 7 dilim ve üzeri ekmek tükettikleri görülmektedir. Tanık (2006) yaptığı çalışmada tüketicilerin günlük satın aldıkları ekmek miktarlarını \%47'si 3-4 adet, \%23'ü 5-7 adet, \%19'u 1-2 adet ve \%11'i 8 ve üzeri adet ekmek olarak belirlemiştir. Aydın ve Yıldız (2011), yaptıkları çalışmaya katılan kişilerin $\% 4,8$ 'inin günde 1 dilim, \%13,8'inin 2 dilim ekmek tüketirken, \%22,3'ünün çeyrek ekmek, \%32,3'ünün yarım ekmek, \%23,0'1nın tüm ekmek ve \%4'ünün diğer oranlarda ekmek tükettiğini belirtmişlerdir. TUBER (2019) verilerine göre 1 dilim ince ekmek $25 \mathrm{~g}$ olarak belirtilmiştir. İkikat Tümer vd. (2019) yaptıkları çalışmada kişi başı günlük ekmek tüketiminin ortalama $212 \mathrm{~g}$ olduğunu belirtmiştir. 1 ince dilim ekmek $25 \mathrm{~g}, 1$ orta dilim ekmek $30 \mathrm{~g}$ olarak hesaplandığında, kişi başı ortalama 8 dilim ekmek tükettikleri ifade edilmiştir. Çalışmamıza katılan tüketicilerin çoğunluğu ise günde 3-4 dilim ekmek tükettiklerini bildirmiştir. Adıgüzel ve Kızılaslan (2020) çalışmalarında tüketicilerin günlük ekmek tüketim miktarlarını \%33,09'u $250 \mathrm{~g}$ ve altı, $\% 42,65$ 'i 250-350 $\mathrm{g}$ aralığında ve \%24,26's1 $351 \mathrm{~g}$ ve üzeri şeklinde belirlemiştir. Ayrıca, katılımcıların en çok somun ekmeği (\% 54.2) ve buğday ekmeği (\% 21.7) tükettiği tespit edilmiştir.

Çizelge 2. Katılımcıların ekmek tüketim alıskanlıkları

Table 2. Bread consumption habits of the participants

\begin{tabular}{|c|c|c|c|}
\hline $\begin{array}{l}\text { Ekmek Tüketim Özellikleri } \\
\text { Bread Consumption Features }\end{array}$ & & $\begin{array}{l}\text { Say1 (n) } \\
\text { Number }\end{array}$ & $\begin{array}{l}\text { Oran }(\%) \\
\text { Rate }\end{array}$ \\
\hline \multirow{5}{*}{$\begin{array}{l}\text { Günlük Ekmek Tüketimi } \\
\text { (Dilim) } \\
\text { Daily Bread Consumption (Slice) }\end{array}$} & $1-2$ & 27 & 32,5 \\
\hline & $3-4$ & 36 & 43,4 \\
\hline & $5-6$ & 15 & 18,1 \\
\hline & 7 ve üzeri & 5 & 6 \\
\hline & Toplam (Total) & 83 & 100 \\
\hline \multirow{10}{*}{$\begin{array}{l}\text { Ekmek Çeşidi } \\
\text { Bread Type }\end{array}$} & $\begin{array}{l}\text { Somun Ekmeği } \\
\text { Loaf Bread }\end{array}$ & 45 & 54.2 \\
\hline & $\begin{array}{l}\text { Karış1k Tahillı Ekmek } \\
\text { Mixed Grain Bread }\end{array}$ & 4 & 4.8 \\
\hline & $\begin{array}{l}\text { Tam Buğday Ekmeği } \\
\text { Whole wheat bread }\end{array}$ & 18 & 21,7 \\
\hline & $\begin{array}{l}\text { Çavdar Ekmeği } \\
\text { Rye Bread }\end{array}$ & 3 & 3.6 \\
\hline & $\begin{array}{l}\text { Ekşi Mayalı Ekmek } \\
\text { Sourdough Bread }\end{array}$ & 3 & 3.6 \\
\hline & Kepek Ekmeği & 7 & \\
\hline & Bran bread & 7 & 8.4 \\
\hline & $\begin{array}{l}\text { Karabuğday Ekmeği } \\
\text { Buckwheat Bread }\end{array}$ & 1 & 1.2 \\
\hline & $\begin{array}{l}\text { Diğer } \\
\text { Other }\end{array}$ & 2 & 2.4 \\
\hline & Toplam ((Total) & 83 & 100 \\
\hline
\end{tabular}


Tüketicilerin ülkemizdeki ekmek tüketim alışkanlıklarının incelendiği çalışmalarda; \%75'i beyaz buğday ekmeği, \%68,75-\%77,21'inin somun ekmeği, \%22,05'inin köy ekmeği, \%14.70'inin esmer ekmek, \%12.13'ünün çiçek ekmek, \%8,26-14'ünün pide ve \%10.29'unun Trabzon ekmeği \%5,41'inin lavaş, \%61,03'ünün tam buğday ekmeği, \%5,22-39,97'sinin kepek ekmeği, \%1-37,13'ünün çavdar ekmeği, $\% 7,55$ 'inin kepekli-çavdar ekmeği, \%5,21'inin taş firın ekmeği ve \%1,77'sinin diğer ekmek çeşitlerini tükettiği rapor edilmiştir (Adıgüzel ve Kızılaslan, 2020; Ekmekçi Bal vd., 2013; İkikat Tümer vd., 2019; Tanik, 2006; Uzundumlu vd., 2018). Çalışmamıza katılan 83 tüketici, literatürdeki çalışmalara benzer şekilde en çok somun ekmeği, tam buğday ekmeği ve kepek ekmeği tercih ettiklerini belirtmişlerdir.

Duyusal analiz panelinde, katılımcılara tattıkları ekmeklere yönelik üretimde kullanılan katkı tipi, maya tipi ve un tipi tahminleri de sorulmuştur. Çalışmamızda ekmek üretiminde, katk1 tipi: bitki unu, maya tipi: kuru maya ve un tipi: buğday unu kullanılmıstır. Katılımcıların kontrol ekmeği, karahindiba unu katk1l (K1, K2 ve K3), civanperçemi unu katk1lı (C1, C2 ve C3) ekmekler ile ilgili katk1, maya ve un tipi tahminlerine yönelik tahmin sonuçlarına göre; tüketiciler zenginleştirilmiş ekmeklere katılan bitki unlarının yeşil ve sar1ya yakın renginden dolayı ekmek hamurunun renginin değişmesi, tüketicilerde buğday unu değil de tam buğday unu veya çavdar unu kullanıldığ1 algisı oluşturmuştur. Ekmeklerde bitki unlarından kaynaklı ekşi ve acı tat algıları da ekşi maya kullanıldığı alg1sı oluşturmuştur. Bu durum tüketici tahminlerine de yansımıştır. Konu yiyecekler olduğunda renk algısının etkisi çok yüksek olduğu ve yiyecek renginin tonu, yiyeceğin taze veya bayat olması hakkında fikir verdiği belirtilmiştir (Ahbap, 2014). Katılımcıların ekmeklerin katki tipi, maya tipi ve un tipi tahminlerine yönelik veriler genel olarak değerlendirildiğinde; katılımcıların katk1 tiplerinin tahmini incelendiğinde, genel olarak bütün ekmeklerde çoğunlukla bitki tipini doğru tahmin etmişlerdir. Katılımcıların maya tipi tahminlerinde, ekşi maya yönünde tahminde bulundukları görülmüştür. Bu durumun bitkilerin sahip olduğu acı ve ekşimsi tattan kaynaklandığ1 düşünülmektedir. Tüketiciler ekmeklerdeki ekşsi maya kokusundan dolayı sağlıklı ve doğal bir ekmek olarak algılamışlardır. Katılımcıların un çeşidi tahminlerinin ise bitki unu rengine göre tam buğday unu, çavdar unu, yulaf unu vb. değişkenlik gösterdiği tespit edilmiştir. Un tahminleri dikkate alındığında ise duyusal analiz sirasinda katılımcların ekmek renginden yola çıkarak un tahmininde bulunduğu gözlemlenmiş olup, bitkiler ekmeğe kendine özgü bir renk kattığı için un tahminlerinin kişiden kişiye çok farklllık gösterdiği düşünülmektedir.

\section{Ekmeklerin Görünüş Özellikleri}

Görünüş özellikleri, ekmeklerin hacim, kabuk rengi, iç rengi ve gözenek yapısı, şekil simetrisi açısından incelenmiş sonuçları Çizelge 3'te verilmiştir.

Ekmeklerin görünüş özellikleri incelendiğinde, hacim özelliği yönünden en yüksek değeri 3.92 ile K3 ekmeği alırken, en düşük değeri ise 3.46 ile kontrol ekmeği almıştır. LSD testi sonuçlarına göre, kontrol örneğinin hacim puanı $\mathrm{C} 2$ ekmeği ile benzer bulunmuş olup $\left(\begin{array}{ll}P & <0.05\end{array}\right)$ diğer zenginleştirilmiş ekmek örneklerinden farklı bulunmuştur $(P<0.05)$. Bu sonucun yoğurma sırasındaki farklilıklardan kaynaklandığ düşünülmektedir. Tibbi bitkilerce zenginleştirilmiş ekmeklerin kabuk rengi puanları incelendiğinde, puanların 3.18-3.86 arasında değiştiği görülmüştür. En düşük puan 3.18 ile kontrolde, en yüksek puan 3.86 ile C1 ekmeğinde tespit edilmiştir. LSD testi sonuçlarına göre, bitki unu katk1l ekmeklerin kabuk rengi ile kontrol ekmeği arasında önemli $(P<0.05)$ bir farklilik olduğu görülmüsstür. $\mathrm{Bu}$ durumun, bitkilerin kendilerine has olan renklerinin ekmek hamuruna geçirmesinden kaynaklandığı düşünülmektedir. Tüketiciler ekmeklerin rengindeki koyulaşmayı tam buğday unu kullanımı ile ilişkilendirmiş ve daha doğal bir ekmek olduğunu düşünmüşlerdir. Duyusal analiz panelindeki tüketici tahmini sonuçlar1 bu sonucu desteklemektedir. Ekmeklerin iç rengi puanları incelendiğinde, tıbbi bitki unu ilavesi ile üretilen ekmeklerin renk puanları 3.42-3.80 arasında değişmiş olup, en yüksek puanı C3 ekmeği almıştır. LSD test 
sonuçlarına göre, ekmek iç rengi puanlarında, kontrole göre önemli bir artış gözlenmiştir $(P$ $<0.05)$. Ekmeklerin gözenek yapısı puanları incelendiğinde, puanların 3.65-3.88 arasında değiştiği görülmüsstür. En düşük puanı 3.65 ile kontrol ve C2 ekmekleri almış olup, en yüksek puan 3.88 ile K2 ekmeği almıştır. LSD testine göre, ekmeklerin gözenek yapısı özellikleri arasında önemli bir farklilık gözlenmemiştir $(P$ $<0.05)$. Ekmeklerin şekil simetrisi puanlar1 incelendiğinde, C2 ekmeği en düşük puanı (4.04),
K1 ekmeği ise en yüksek puanı (4.18) almıştır. LSD testine göre, ekmeklerin şekil simetrisi özellikleri arasında önemli bir fark gözlenmemiştir $(P<0.05)$. Üretim şeklinin standart olması ve tekniğin doğru uygulanması nedeniyle ekmek şekilleri benzer bulunmuştur. Tüketiciler tarafindan yapılan duyusal değerlendirme sonucuna göre tüm ekmekler 3 ve 4 üzerinde puan alıp görünüş özelliği yönünden "kabul edilebilir" ve "iyi”" olarak nitelendirilmiştir.

Çizelge 3. Ekmeklerin görünüş özelliklerine ait duyusal analiz sonuçları*1

Table 3. Sensory analysis results of the appearance properties of bread

\begin{tabular}{|c|c|c|c|c|c|}
\hline \multirow[b]{2}{*}{$\begin{array}{l}\text { Örnek } \\
\text { Sample }\end{array}$} & \multicolumn{5}{|c|}{$\begin{array}{l}\text { Görünüş } \\
\text { Appearance }\end{array}$} \\
\hline & $\begin{array}{l}\text { Hacim } \\
\text { Volume }\end{array}$ & $\begin{array}{l}\text { Kabuk Rengi } \\
\text { Shell color }\end{array}$ & $\begin{array}{l}\text { İç Rengi } \\
\text { Interior color }\end{array}$ & $\begin{array}{c}\text { Gözenek Yapis1 } \\
\text { Pore structure }\end{array}$ & $\begin{array}{l}\text { Şekil Simetrisi } \\
\text { Shape symmetry }\end{array}$ \\
\hline $\mathrm{K}$ & $3.46 \pm 1.10^{\mathrm{b}}$ & $3.18 \pm 1.19^{b}$ & $3.42 \pm 1.25^{\mathrm{b}}$ & $3.65 \pm 1.18^{\mathrm{a}}$ & $4.12 \pm 1.02^{\mathrm{a}}$ \\
\hline K1 & $3.80 \pm 1.02^{\mathrm{a}}$ & $3.63 \pm 1.00^{\mathrm{a}}$ & $3.77 \pm 0.99^{a}$ & $3.78 \pm 1.16^{\mathrm{a}}$ & $4.18 \pm 0.91^{\mathrm{a}}$ \\
\hline $\mathrm{K} 2$ & $3.84 \pm 1.02^{\mathrm{a}}$ & $3.66 \pm 1.00^{\mathrm{a}}$ & $3.76 \pm 1.12^{\mathrm{ab}}$ & $3.88 \pm 1.12^{\mathrm{a}}$ & $4.07 \pm 1.03^{\mathrm{a}}$ \\
\hline K3 & $3.92 \pm 1.12^{\mathrm{a}}$ & $3.67 \pm 1.19^{\mathrm{a}}$ & $3.76 \pm 1.27 \mathrm{ab}$ & $3.87 \pm 1.11^{\mathrm{a}}$ & $4.14 \pm 1.03^{a}$ \\
\hline C1 & $3.80 \pm 1.09^{a}$ & $3.86 \pm 1.06^{\mathrm{a}}$ & $3.75 \pm 1.08^{\mathrm{ab}}$ & $3.83 \pm 1.14^{a}$ & $4.12 \pm 0.99^{a}$ \\
\hline $\mathrm{C} 2$ & $3.69 \pm 1.09 \mathrm{ab}$ & $3.65 \pm 1.02^{\mathrm{a}}$ & $3.58 \pm 1.12^{\mathrm{ab}}$ & $3.65 \pm 1.25^{\mathrm{a}}$ & $4.04 \pm 1.10^{\mathrm{a}}$ \\
\hline $\mathrm{C} 3$ & $3.83 \pm 1.05^{\mathrm{a}}$ & $3.83 \pm 0.99^{\mathrm{a}}$ & $3.80 \pm 1.06^{\mathrm{a}}$ & $3.73 \pm 1.13^{\mathrm{a}}$ & $4.12 \pm 1.05^{\mathrm{a}}$ \\
\hline
\end{tabular}

*Aynı sütunda farklı harflerle gösterilen ortalamalar arasında istatistiksel olarak önemli fark bulunmaktadır ( $\leq 0.05)$. Sonuçlar ortalama \pm standart sapma şeklinde verilmiştir.

* Mean values represented by the same letters within the same column are not significantly different at $P \leq 0.05$.

Data are expressed as means \pm standard deviations

${ }^{1} \mathrm{~K}$ : Kontrol ekmeği; K1, K2 ve K3: Karahindiba unu katkılı ekmekler; C1, C2 ve C3: Civanperçemi unu katkılı ekmekler)

${ }^{1} \mathrm{~K}$ : control bread; K1, K2 and K3: bread enriched with dandelion flour; C1, C2 and C3: bread enriched with yarrow flour

\section{Ekmeklerin Tekstür Özellikleri}

Farklı çeşit ve oranlarda tıbbi bitki unu ilave edilerek üretilen ekmeklerin tekstür özellikleri, çiğnenebilirlik, sertlik, yapışkanlık ve ufalanma özellikleri açısından duyusal olarak değerlendirilmiş ve sonuçlar Çizelge 4'te verilmiştir.

Ekmeklerin çiğnenebilirlik özellikleri incelendiğinde, en yüksek puan 3.89 ile kontrol ekmeğine verilirken, en düşük puan 3.23 ile C3 ekmeğine verilmiştir. LSD testi sonuçları incelendiğinde, C1, C2 ve C3 ekmeklerinin kontrolden önemli düzeyde farklı olduğu görülmektedir $(P<0.05)$. Tüketicilerin verdikleri puanlara göre, karahindiba bitki unu katk1lı ekmeklerin çiğnenebilirliği, civanperçemi unu katkı1ı ekmeklere göre daha iyi bulunmuştur $(P$ <0.05). Ekmeklerin sertlik özellikleri incelendiğinde ise, puanların 3.42-3.86 arasında değiştiği, kontrol ekmeğinin en yüksek puanı aldığı tespit edilmiştir. Bitki unu katkılı ekmeklerin kontrol ekmeğine göre önemli oranda farklı olduğu görülmüştür $(P<0.05)$. Ekmeklerin yapışkanlık özellikleri incelendiğinde, puanların 3.28-3.57 arasında değiştiği ve istatistiksel olarak önemli bir farkllık bulunmadığ tespit edilmiştir (P <0.05). Ekmeklerin ufalanma özellikleri incelendiğinde, puanların 3.30-3.67 arasında değiştiği ve ekmekler arasında istatistiksel olarak 
anlamlı bir farklılık olmadığ1 görülmüştür $(P$ $<0.05)$. Tüketiciler tarafindan yapılan duyusal değerlendirme sonucuna göre, tüm ekmekler 3 ve üzerinde puan alıp tekstür özelliği yönünden

"kabul edilebilir" olarak nitelendirilmiştir.

Çizelge 4. Ekmeklerin tekstür özeliklerine ait duyusal analiz sonuçları*1 Table 4. Sensory analysis results of the texture properties of bread*1

\begin{tabular}{|c|c|c|c|c|}
\hline \multirow{3}{*}{$\begin{array}{l}\text { Örnek } \\
\text { Sample }\end{array}$} & \multicolumn{4}{|c|}{$\begin{array}{l}\text { Tekstür } \\
\text { Texture }\end{array}$} \\
\hline & Çiğnenebilirlik & Sertlik & Yapışkanlık & Ufalanma \\
\hline & Chewiness & Hardness & Adhesiveness & Crumbling \\
\hline $\mathrm{K}$ & $3.89 \pm 1.13^{\mathrm{a}}$ & $3.86 \pm 1.08^{\mathrm{a}}$ & $3.43 \pm 1.32^{\mathrm{a}}$ & $3.67 \pm 1.29^{\mathrm{a}}$ \\
\hline K1 & $3.66 \pm 1.09^{\mathrm{ab}}$ & $3.75 \pm 0.97 \mathrm{ab}$ & $3.31 \pm 1.18^{\mathrm{a}}$ & $3.58 \pm 1.26^{\mathrm{a}}$ \\
\hline K2 & $3.52 \pm 1.30 \mathrm{abc}$ & $3.66 \pm 1.15^{\mathrm{ab}}$ & $3.40 \pm 1.31^{\mathrm{a}}$ & $3.59 \pm 1.27^{\mathrm{a}}$ \\
\hline K3 & $3.52 \pm 1.27 \mathrm{abc}$ & $3.64 \pm 1.16^{\mathrm{ab}}$ & $3.37 \pm 1.30^{\mathrm{a}}$ & $3.51 \pm 1.38^{\mathrm{a}}$ \\
\hline C1 & $3.46 \pm 1.26^{\mathrm{bc}}$ & $3.64 \pm 1.17 \mathrm{ab}$ & $3.57 \pm 1.27^{\mathrm{a}}$ & $3.54 \pm 1.28^{\mathrm{a}}$ \\
\hline C2 & $3.40 \pm 1.31 \mathrm{bc}$ & $3.53 \pm 1.23 \mathrm{ab}$ & $3.37 \pm 1.27 \mathrm{a}$ & $3.36 \pm 1.27 \mathrm{a}$ \\
\hline C3 & $3.23 \pm 1.32^{c}$ & $3.42 \pm 1.31^{\mathrm{b}}$ & $3.28 \pm 1.37 \mathrm{a}$ & $3.30 \pm 1.31^{\mathrm{a}}$ \\
\hline
\end{tabular}

*Aynı sütunda farklı harflerle gösterilen ortalamalar arasında istatistiksel olarak önemli fark bulunmaktadır ( $\mathrm{P}$ $\leq 0.05)$. Sonuçlar ortalama \pm standart sapma șeklinde verilmiștir.

* Mean values represented by the same letters within the same column are not significantly different at $P \leq 0.05$.

Data are expressed as means \pm standard deviations

${ }^{1} \mathrm{~K}$ : Kontrol ekmeği; K1, K2 ve K3: Karahindiba unu katkılı ekmekler; C1, C2 ve C3: Civanperçemi unu katkılı ekmekler)

${ }^{1} \mathrm{~K}$ : control bread; K1, K2 and K3: bread enriched with dandelion flour; C1, C2 and C3: bread enriched with yarrow flour

\section{Ekmeklerin Tüm Duyusal Özellikleri}

Ekmeklerin tüm duyusal özellikleri görünüș, lezzet/tat, koku, tekstür, ağızda bıraktığı his ve genel kabul edilebilirlik olmak üzere altı ana başlık altında incelenmiştir. Tüm duyusal özelliklere ait sonuçların ortalamaları Çizelge 5’te verilmiştir.

Tüketicilere yapılan duyusal analiz panel formu sonuçlarına göre; ekmeklerin görünüş özellikleri incelendiğinde, puanların 3.57-3.87 arasında değiştiği tespit edilmiştir. LSD testi sonuçlanna göre, tıbbi bitki unu ile zenginleştirilmiş ekmeklerde kontrole göre istatistiksel olarak anlamlı bir artış olduğu görülmüştür $(P<0.05)$. Günümüzde tüketicilerin daha sağlıklı gıdalara olan talebin artması nedeniyle, fonksiyonel, doğal, organik ve katkısız ürünler daha ilgi çekici olmuştur (Özkan Özdemir vd., 2009). Çalışmamızda kullandığımız tıbbi bitki unları ekmeklere doğal bir yap1 kazandırdığı için, tüketiciler görünüş özelliklerine kabul edilebilir puanlar vermiştir. Ekmeklerin lezzet/tat özelliği incelendiğinde, puanların 2.56-3.33 arasinda değiştiği, C2 ve C3 ekmeklerinin lezzet/tat puanlarında diğer ekmeklere göre, istatistiksel olarak anlamlı bir düşüş olduğu tespit edilmiştir $(P$ $<0.05)$ Lezzet/tat puanları açısından istatiksel olarak $(P<0.05)$ en yüksek puan $(3.33) \mathrm{K} 1$ örneğinde tespit edilmiştir. Ekmeklerin koku özelliği incelendiğinde, puanların 2.49-3.51 arasında değiştiği tespit edilmiştir. LSD testi sonuçlar1 incelendiğinde ise C2 ve C3 ekmeklerinin koku puanlarında diğer ekmeklere göre, istatistiksel olarak anlamlı bir düşüş olduğu görülmüştür $(P<0.05)$ Koku puanları açısından istatiksel olarak en yüksek puan K1 (3.51) ve C1 (3.49) örneklerinde tespit edilmiştir. Ekmeklerin tekstür özelliği incelendiğince, puanların 2.27-3.71 arasında değiştiği ve bitki unu ile zenginleştirilmiş ekmeklerin tekstür puanlarında kontrole (3.71) göre, istatistiksel olarak anlamlı bir düşüş olduğu görülmektedir $(P<0.05)$ Kontrole en yakın puanı K1 (3.58) ekmeği almıştır. Ekmeklerin ağızda bıraktığ1 his özelliği incelendiğinde, puanların 2.27-3.71 arasında değiştiği ve bitki unu ile zenginleştirilmiş ekmeklerde kontrole göre, istatistiksel olarak anlamlı bir düşüş olduğu tespit edilmiştir $(P<0.05)$. Kontrol örneğine en yakın puanı (3.42) K1 ekmeği almıştır. Ekmeklerin genel kabul edilebilirliği incelendiğinde, puanların 2.31- 
3.72 arasında değiştiği ve bitki unu ile zenginleştirilmiş ekmeklerde kontrol ekmeğine göre, istatistiksel olarak anlamlı bir düşüş olduğu tespit edilmiştir $(P<0.05)$. Kontrol örneğine en yakın puanı (3.58) K1 ekmeği almıştır. En yüksek genel kabul edilebilirlik puanları sirasiyla Kontrol $>\mathrm{K} 1>\mathrm{K} 3>\mathrm{K} 2 \geq \mathrm{C} 1>\mathrm{C} 2>\mathrm{C} 3 \quad$ şeklinde sıralanmıştır. Tüketiciler tarafindan yapılan duyusal değerlendirme sonucuna göre C2 ve C3 ekmeği hariç, tüm ekmekler 3 ve üzerinde puan alıp genel kabul edilebilirlik özelliği yönünden "kabul edilebilir" olarak nitelendirilmiştir. C2 ve C3 ekmeklerinin düşük puan almasının nedeninin civanperçemi bitkisinden kaynaklı acılık maddesinin ekmeklerin lezzet ve aromasinı olumsuz yönde etkilemesinden kaynaklandığ1 düşünülmektedir.

Çizelge 5. Ekmeklerin tüm duyusal özeliklerine ait analiz sonuçları*1

Table 5. Analysis results of all sensory properties of bread*1

\begin{tabular}{|c|c|c|c|}
\hline \multirow{3}{*}{$\begin{array}{l}\text { Örnek } \\
\text { Sample }\end{array}$} & \multicolumn{3}{|c|}{$\begin{array}{l}\text { Duyusal Özellikler } \\
\text { Sensory Properties }\end{array}$} \\
\hline & Görünüş & Lezzet/Tat & Koku \\
\hline & Appearance & Flavor/Taste & Smell \\
\hline K & $3.57 \pm 0.89^{\mathrm{b}}$ & $3.23 \pm 1.18^{\mathrm{ab}}$ & $3.39 \pm 1.31 \mathrm{ab}$ \\
\hline K1 & $3.83 \pm 0.80^{\mathrm{ab}}$ & $3.33 \pm 1.08^{a}$ & $3.51 \pm 1.10^{\mathrm{a}}$ \\
\hline $\mathrm{K} 2$ & $3.84 \pm 0.84^{a}$ & $3.14 \pm 1.27 \mathrm{ab}$ & $3.41 \pm 1.20^{\mathrm{ab}}$ \\
\hline K3 & $3.87 \pm 0.87 a$ & $3.18 \pm 1.32^{\mathrm{ab}}$ & $3.39 \pm 1.35^{\mathrm{ab}}$ \\
\hline $\mathrm{C} 1$ & $3.87 \pm 0.89^{a}$ & $3.16 \pm 1.41^{\mathrm{ab}}$ & $3.49 \pm 1.47 \mathrm{a}$ \\
\hline $\mathrm{C} 2$ & $3.72 \pm 0.93^{\mathrm{ab}}$ & $2.85 \pm 1.33^{\mathrm{bc}}$ & $2.99 \pm 1.45^{b c}$ \\
\hline $\mathrm{C} 3$ & $3.86 \pm 0.87^{\mathrm{a}}$ & $2.56 \pm 1.34^{\mathrm{c}}$ & $2.79 \pm 1.48^{c}$ \\
\hline Min-Max & $3.57-8.87$ & $2.56-3.33$ & $2.79-3.51$ \\
\hline \multirow[t]{2}{*}{ Ort $\pm S D$} & $3.80 \pm 0.11$ & $3.06 \pm 0.27$ & $3.28 \pm 0.28$ \\
\hline & $\begin{array}{l}\text { Tekstür } \\
\text { Texture }\end{array}$ & $\begin{array}{l}\text { Ağızda Biraktığ1 His } \\
\text { Mouth Feeling }\end{array}$ & $\begin{array}{l}\text { Genel Kabul Edilebilirlik } \\
\text { General Acceptability }\end{array}$ \\
\hline $\mathrm{K}$ & $3.71 \pm 0.94^{a}$ & $3.71 \pm 1.13^{a}$ & $3.72 \pm 1.09 a$ \\
\hline K1 & $3.58 \pm 0.89 \mathrm{ab}$ & $3.42 \pm 1.24 \mathrm{ab}$ & $3.54 \pm 1.15^{\mathrm{ab}}$ \\
\hline $\mathrm{K} 2$ & $3.54 \pm 1.05^{\mathrm{ab}}$ & $2.99 \pm 1.43^{\mathrm{cd}}$ & $3.04 \pm 1.36^{\mathrm{cd}}$ \\
\hline K3 & $3.51 \pm 1.10^{\mathrm{ab}}$ & $3.18 \pm 1.44 \mathrm{bc}$ & $3.24 \pm 1.39 \mathrm{bc}$ \\
\hline C1 & $3.55 \pm 1.06^{a b}$ & $2.98 \pm 1.44 \mathrm{~cd}$ & $3.00 \pm 1.37 \mathrm{~cd}$ \\
\hline $\mathrm{C} 2$ & $3.42 \pm 1.09 \mathrm{ab}$ & $2.75 \pm 1.50^{\mathrm{d}}$ & $2.81 \pm 1.45^{\mathrm{d}}$ \\
\hline C3 & $3.31 \pm 1.18^{\mathrm{b}}$ & $2.27 \pm 1.47 \mathrm{e}$ & $2.31 \pm 1.36^{\mathrm{e}}$ \\
\hline Min-Max & $3.31-3.71$ & $2.27-3.71$ & $2.31-3.72$ \\
\hline Ort $\pm S D$ & $3.52 \pm 0.13$ & $3.04 \pm 0.47$ & $3.09 \pm 0.47$ \\
\hline
\end{tabular}

*Aynı sütunda farklı harflerle gösterilen ortalamalar arasında istatistiksel olarak önemli fark bulunmaktadır (P $\leq 0.05)$. Sonuçlar ortalama \pm standart sapma şeklinde verilmiştir.

* Mean values represented by the same letters within the same column are not significantly different at $P \leq 0.05$.

Data are expressed as means \pm standard deviations (SD)

${ }^{1} \mathrm{~K}$ : Kontrol ekmeği; K1, K2 ve K3: Karahindiba unu katkılı ekmekler; C1, C2 ve C3: Civanperçemi unu katkılı ekmekler)

${ }^{1} \mathrm{~K}$ : control bread; K1, K2 and K3: bread enriched with dandelion flour; C1, C2 and C3: bread enriched with yarrow flour

Ekmeklerin duyusal analiz sonuçlarının radar grafiğinde değişimi Şekil 2'de verilmiştir. Genel olarak değerlendirildiğinde tüm ekmeklerin duyusal özelliklerinin ortalamaları alındığında 3 ve üzerinde tespit edilmiş kabul edilebilir özelliklere sahip oldukları belirlenmiştir. Ekmek duyusal özelliklerinden "görünüş", lezzet/tat, koku, tekstür, ağızda bıraktı̆̆ his ve genel kabul edilebilirlik ortalamaları arasında istatistiksel olarak $(P<0.05)$ anlamlı bir farklılık vardır. 
Tüketicilerin verdikleri puanlara göre, karahindiba bitki unu katk1lı ekmeklerin genel duyusal özellikleri, civanperçemi unu katkılı ekmeklere göre daha iyi bulunmuştur $(P<0.05)$. Duyusal analiz panelinde kullanilan karahindiba ve civanperçemi bitki unu katkılı zenginleştirilmiş ekmeklere ait görseller Şekil 3’te verilmiştir

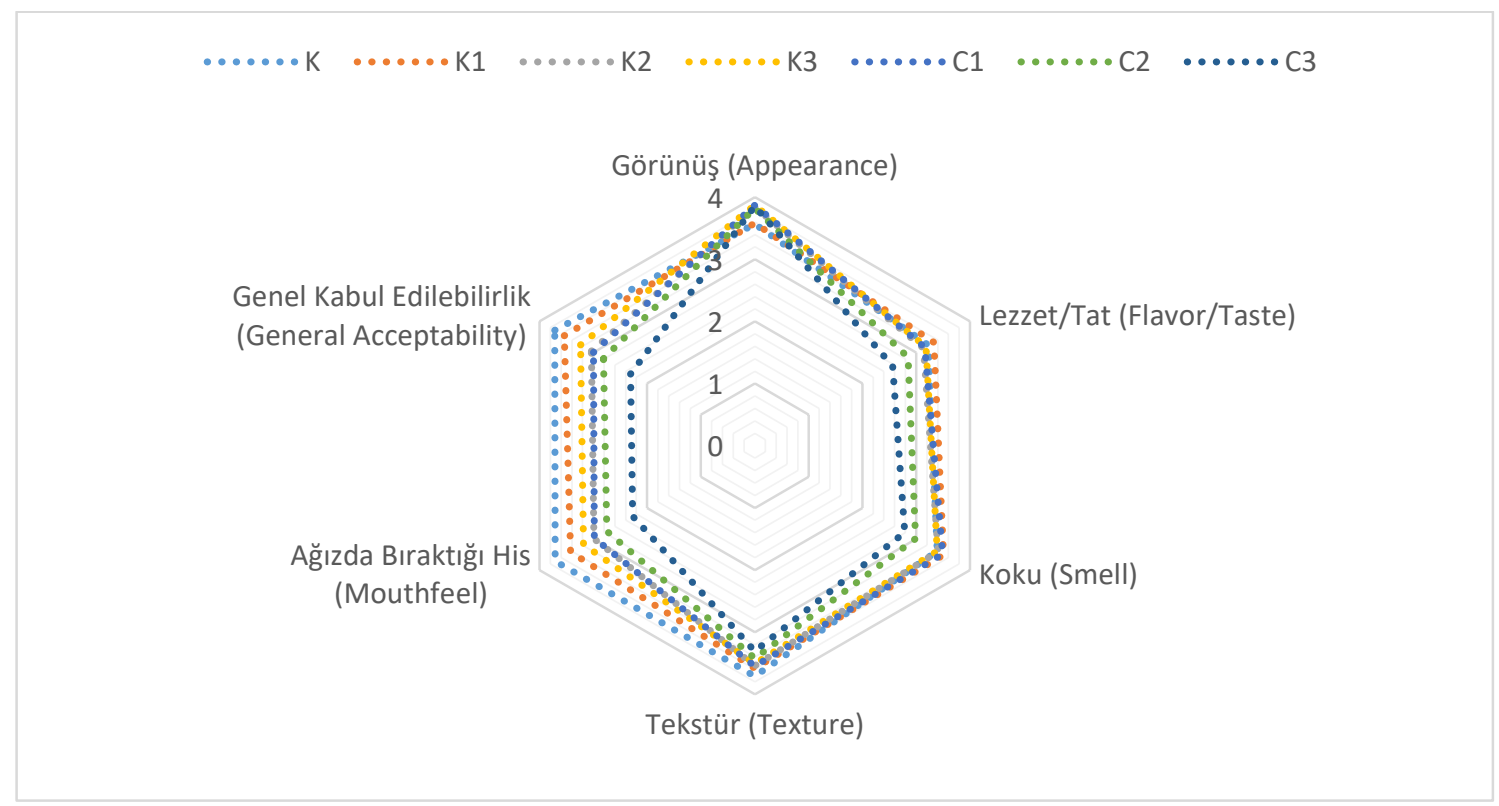

Şekil 2. Tıbbi bitki unu katkılı zenginleştirilmiş ekmeklerin duyusal analiz sonuçlarının radar grafiğinde değişimi (K: tıbbi bitki içermez, sadece buğday unu; K1: \%1 karahindiba unu, K2: \%2 karahindiba unu,

K3: \%3 karahindiba katkılı ekmek; C1: \%1 civanperçemi unu, C2: \%2 civanperçemi unu, C3: \%3 civanperçemi unu katk1lı ekmek)

Figure 2. The change in the sensory analysis results of the bread enriched with medicinal plant flour in the radar chart (K: without medicinal plant, only wheat flour; K1:1\% dandelion flour, K2: $\%$ dandelion flour, K3: $3 \%$ dandelion flour-enriched bread; C1: 1\% yarrow flour, C2: 2\% yarrow flour, C3: 3\% yarrow flour-enriched bread)

Literatüre yer alan çalışmalar incelendiğinde; Yarpuz (2011), yaptığı çalışmada, lüpen unu, karabuğday unu, guar gam ve emilgatör kullanarak ürettiği zenginleştirilmiş ekmeklerin duyusal analiz sonuçlarında $\% 10$ ve $\% 20$ oranında lüpen unu içeren ekmeklerin tat, koku, yumuşaklık ve genel beğeni özelliklerinde en yüksek puanı aldıklarını bildirmişlerdir. Erdemir (2015), ısıl işlem görmüş bakla ezme tozu ile zenginleştirdiği ekmeklerin duyusal analizler sonucunda bakla ezme tozu ilave oranı arttıkça ekmeklerin renk oranlarında azalma olurken, genel olarak \%15 oranında katkı içeren ekmeklerin duyusal özelliklerinde anlamlı bir farklılik olduğunu bildirmişlerdir. Arslan Burnaz vd. (2018), tıbbi ve aromatik bitkiler ile ekmeğin fenolik madde içeriğini zenginleştirmeyi amaçlamışlar ve sarı haşhaş, mavi haşhaş, kişniş, keten tohumu, mahlep, tarçın ve zerdeçal kullanmışlardır. Duyusal analizde tarçınlı ekmek en yüksek kabul edilebilirliği gösterirken, kişnişli ekmeğin kabul edilebilir nitelikte olmadığı bildirilmiştir. Barışık ve Tavman (2018), nohut unu kullanarak zenginleştirdikleri glütensiz ekmeklerin duyusal değerlendirmesi sonucunda $\% 40$ oranında nohut unu ile zenginleştirilen ekmek en yüksek puanı alırken nohut unu içermeyen ekmek en düşük değeri almışır. Bunun yanı sıra nohut unu miktarı arttıkça ekmekte meydana gelen sarılığın panelistlerce daha çok beğenildiği bildirilmiştir. Çalışmamızda da belirtilen literatür çalışmalarına benzer şekilde ekmeklerin duyusal özelliklerini iyileştiren sonuçlara ulaşılmıştır. Çalışma sonuçları incelendiğinde, duyusal özellikler tüketiciden tüketiciye değişiklik göstermekle birlikte, genel olarak tüm ekmekler ortalama puan açısından 
kabul edilebilir sonuçlar göstermiştir. Tüketicilerin verdikleri genel kabul edilebilitlik puanları açısından; en çok beğenilen tıbbi bitki unu katk1lı ekmek K1 \%1 karahindiba bitki unu

katkılı ekmek), en az beğenilen ise C3 (\%3 civanperçemi bitki unu katkılı ekmek) ekmeği olmuştur.

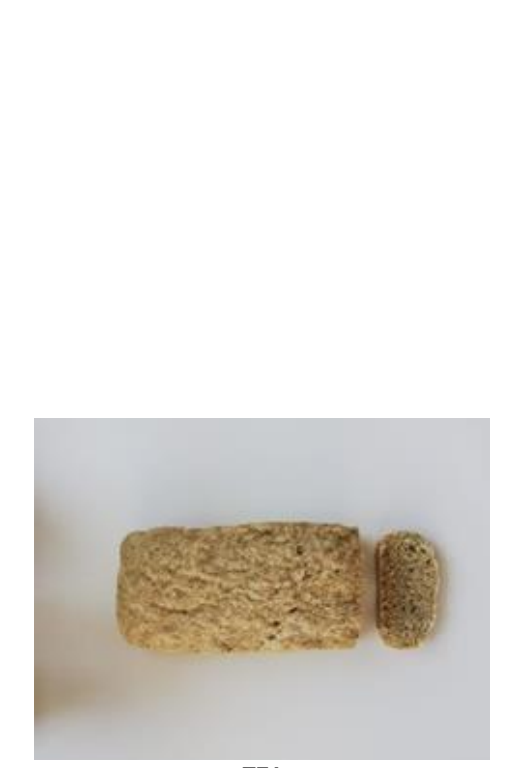

K1

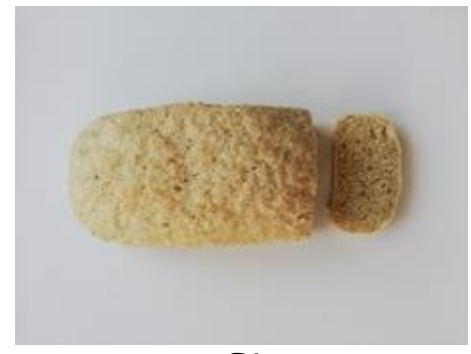

C1

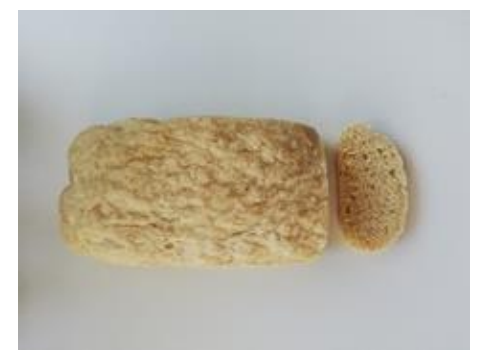

K

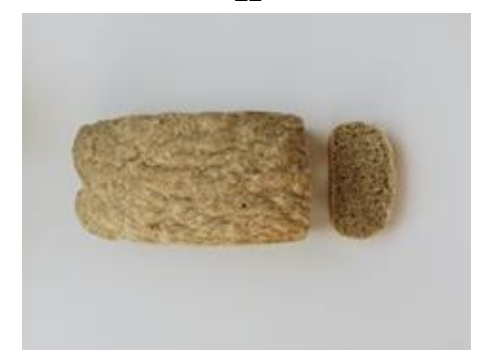

K2

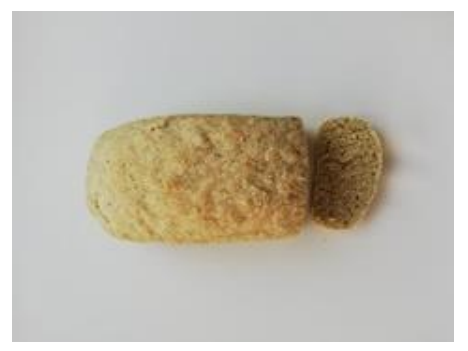

C2

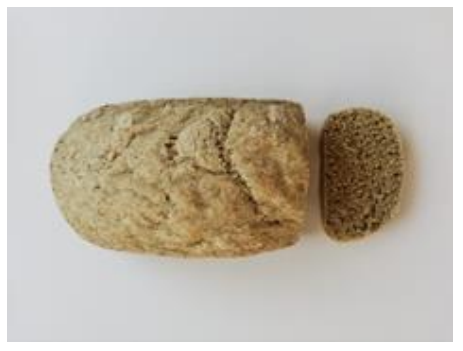

K3

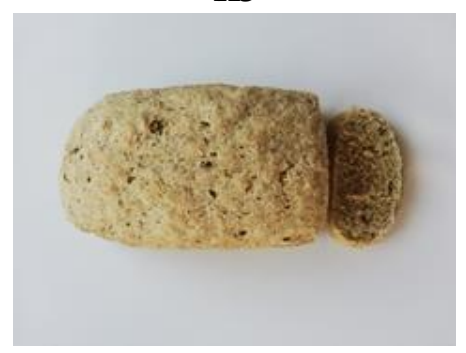

C3

Şekil 3. Duyusal analizde kullanılan ekmek örnekleri ((K: tıbbi bitki içermez, sadece buğday unu; K1: $\% 1$ karahindiba unu, K2: \%2 karahindiba unu, K3: \%3 karahindiba unu zenginleştirilmiş ekmek; C1:

$\% 1$ civanperçemi unu, C2: \%2 civanperçemi unu, C3: \%3 civanperçemi unu ile zenginleştirilmiş ekmek)

Figure 3. Bread samples used in sensory analysis (K: without medicinal plant, only wheat flour; K1:1\% dandelion flour, K2: 2\% dandelion flour, K3: 3\%dandelion flour-enriched bread; C1: 1\% yarrow flour, C2: 2\% yarrow flour, C3: 3\% yarrow flour-enriched bread)

İnsanların beslenmesinde çok önemli bir yeri olan ekmeğin besinsel, duyusal ve fonksiyonel özelliklerinin geliştirilmesi için yapılmış pek çok çalışma mevcuttur. Ancak, çalışma kapsamında kullanılan tıbbi bitkilerden karahindiba ve civanperçemi bitki unlarının ekmek zenginleştirme işleminde kullanıldığı ve duyusal özelliklerin incelendiği bir çalışmaya literatürde rastlanmamıştır.

\section{Duyusal Özelliklerin Satın Alma Niyetine Üzerine Etkisi}

Ekmeklerin duyusal özelliklerinin, tüketicilerin satın alma niyeti üzerindeki etkisini gösteren, duyusal özellik puanlarındaki 1 birimlik artışı, satın alma niyetini kaç birim artıracağına yönelik regresyon denklemleri Şekil 4'te verilmiştir. 


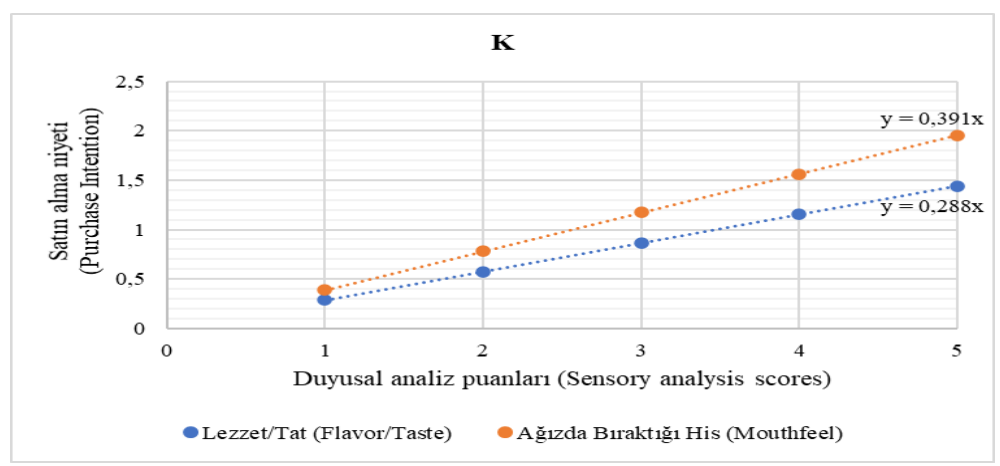

(a)

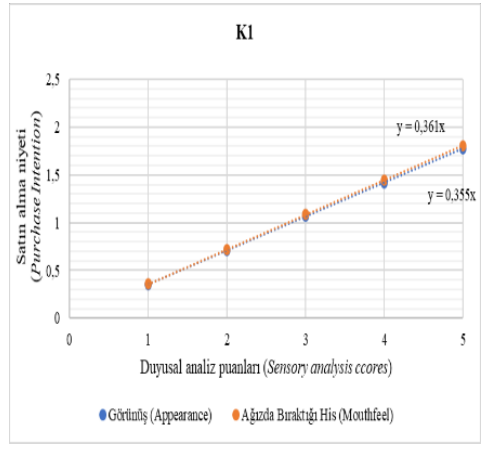

(b)

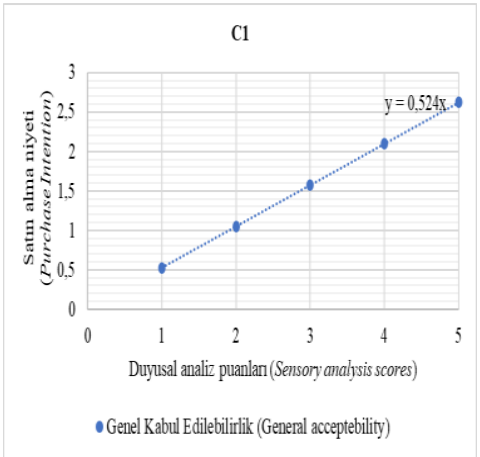

(e)

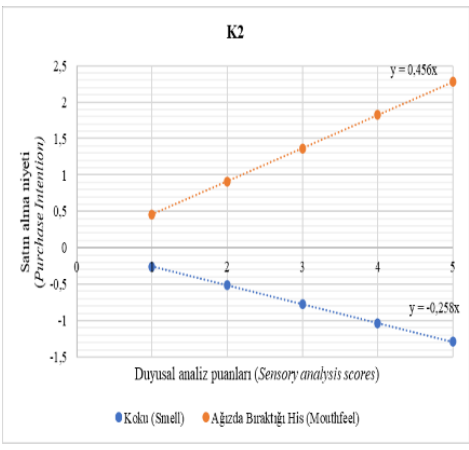

(c)

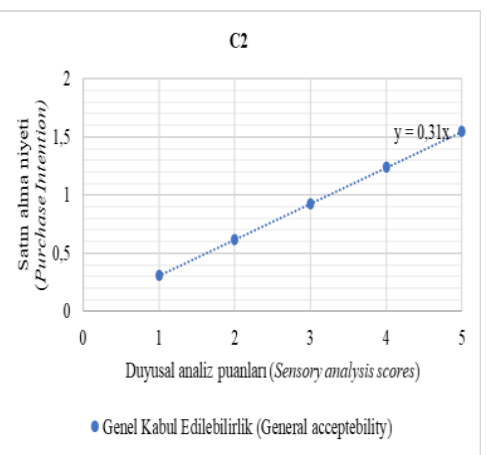

(f)

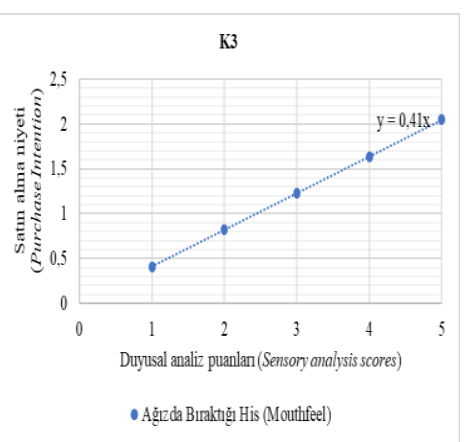

(d)

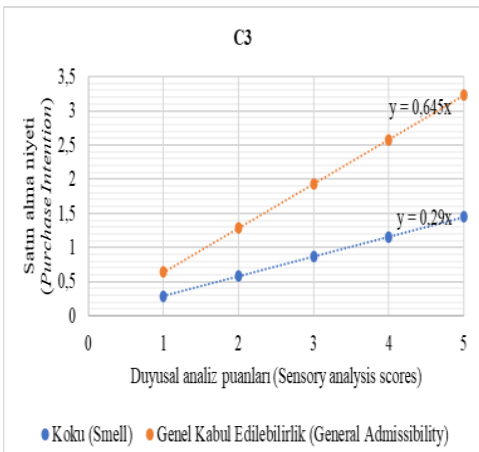

(g)

Şekil 4. Tıbbi bitki unu katkılı zenginleştirilmiş ekmeklerin duyusal özelliklerinin satın alma niyeti üzerine etkisinin regresyon denklemleri (a)-K kontrol ekmeği; (b), (c), (d)-K1, K2, K3 Karahindiba unu katk1lı ekmekler; (e), (f), (g): C1, C2, C3 Civanperçemi unu katk1lı ekmekler)

Figure 4. Regression equations for the effect of sensory properties of bread enriched with medicinal plant flour on purchase intention (a)-K control bread; (b), (c), (d)-K1, K2, K3 bread enriched with dandelion flour, (e), (f), (g): C1, C2, C3 bread enriched with yarrow flour

Ekmeklerin duyusal özelliklerinin satın alama niyeti üzerine etkisi incelendiğinde ekmek duyusal özelliklerinin satın alma niyeti üzerinde olumlu etkisi olduğu tespit edilmiştir. Çalışmamız kapsamında üretilen yedi farklı ekmek formülasyonunun satın alma niyeti üzerinde etkili olan duyusal özellikler çeşitlilik göstermektedir. Duyusal özelliklerden hangilerinin satın alma niyeti üzerinde etkili olduğu ve bu faktörlere bağl1 olarak "satın alma niyeti" davranışının \% değişimi 
regresyon analizi sonuçlarına göre sırasıly; kontrolde lezzet/tat ve ağızda bıraktığ1 his (\%54.6), K1 ekmeğinde görünüş ve ağızda bıraktığı his (\%66), K2 ekmeğinde koku ve ağızda biraktığ1 his (\%70.7), K3 ekmeğinde ağızda bıraktığı his (\%60.3), C1 ekmeğinde genel kabul edilebilirlik (\%63.2), C2 ekmeğinde genel kabul edilebilirlik (\%57.7) ve C3 ekmeğinde genel kabul edilebilirlik (\%70.7) özelliklerinin etkili olduğu tespit edilmiştir. Ekmeklerin duyusal özellikleri ne kadar iyileşirse tüketici satın alma niyeti de o kadar çok arttı̆̆ gözlenmiştir. Satın alma niyeti görsel özellikler yanında tüketicilerin kissisel özelliklerine bağlı olarak da değişebilmektedir.

Tanık (2006), yaptığı çalışmada, tüketicilerin damak tadı ve alışkanlıkları dolayısıyla çoğunlukla beyaz ekmek tükettikleri ve ekmek alırken tat, lezzet, yenilebilirlik, görünüş, renk, depolama süresi gibi kriterlere dikkat ettikleri sonucunu bildirmiştir. Aksoylu vd. (2014), yaptıkları çalışmada ekmek tüketim alışkanlıklarının, tüketicinin cinsiyet, yaş, gelir düzeyi ve meslek grubuna ve ekmeğin tat ve ulaşılabilirliğine göre farkll1ık gösterdiğini rapor etmişlerdir. Bununla birlikte, satın alma alıskanlıkları dikkate alındığında, ekmeklerin tat, sağlıklı, lifli, kolay bulunabilir olması ve fiyatlarının satın alma tercihinde etkili olduğu tespit edilmiştir (Aksoylu vd., 2014). Bu çalışmalar, elde ettiğimiz verileri destekler nitelikte olup, renk, tat, lezzet, koku, görünüş vb. gibi duyusal karakteristikleri tüketici tercihlerini etkilediğini göstermektedir. Panele katılan tüketiciler yeni ürünleri denemeye açı ve istekli bulunmuştur.

\section{SONUÇ}

Araştırma kapsamında seçilen iki tıbbi bitkinin de sağlık açısından faydaları olduğu yapılan literatür çalışmalarında bildirilmiştir. Çalışmamız kapsamında bu bitkilerin farklı bir alanda değerlendirilerek, günlük diyette sıklıkla yer alan ekmeğin zenginleştirilmesi ve dengeli beslenmeye katk1 sağlanması amaçlanmıştır. Araştırma sonucuna göre; değeri az bilinen tıbbi bitkilerin kullanımı toplum sağlığına olumlu yönde fayda sağlayacak ve sürdürülebilir beslenmeyi teşvik edecektir. Ekmeğin zenginleştirilerek tüketilmesi besin içeriklerinin iyileşmesini sağlayacaktır.
Ayrıca karahindiba ve civanperçemi gibi değerli tıbbi bitkilerin besleyici ve fonksiyonel özelliklerinden g1da ve farklı bilim dallarında yararlanılması gerektiği ve yeni ürün geliştirme çalışmalarında fonksiyonel gida katkısı olarak kullanılabileceği düşünülmektedir. Çalışmamızda, ekmeklerin duyusal özellikleri ne kadar iyileşirse tüketici satın alma niyeti de o kadar çok arttı̆̆1, bazı özelliklerin bu durumu daha çok etkilediği tespit edilmiştir. Satın alma niyeti görsel özellikler yanında tüketicilerin kişisel özelliklerine bağlı olarak da değişebileceği düşünülmekte olup, bu konu üzerinde çalışmalar yapılması önerilmektedir. Buna ek olarak duyusal analizler sırasında katılımciların bazı ekmeklerde hafif bir ac1 tat olduğu ve bu tadın iyileştirilmesi durumunda ekmeklerin tüketilebileceği yönünde geri dönüşler alınmıştır. Bu durumun acılık hissedilen tıbbi bitkinin daha düşük oranlarının kullanılması ile giderilebileceği öngörülmekte olup, bu konu üzerine ve zenginleştirilmiş ekmeklerin diğer besleyici özellikleri üzerine çalışmaların yapılması gerektiği düşünülmektedir.

\section{ÇIKAR ÇATIŞMASI BEYANI}

Yazarlar, bu makale ile ilgili başka kişi veya kurumlar ile çıkar çatışması olmadığını beyan eder.

\section{YAZAR KATKILARI}

$\mathrm{Bu}$ çalışma ilk yazarın yüksek lisans tezinden türetilmiştir. Gözde ÖZDEMIR, tez analizlerinin takibi, istatiksel analiz ve yazımını sağlamıştır. Tez danışmanları, Dilek DÜLGER ALTINER ve Yasemin ŞAHAN araştırmanın planlanması, yürütülmesi, istatiksel değerlendirilme ve makale yazım aşamasında görev almıştır. Yazarlar makalenin son halini okumuş ve onaylamışlardır.

\section{TEŞEKKÜR}

Regresyon analizindeki katkılarından dolayı, Kocaeli Üniversitesi, Gastronomi ve Mutfak Sanatları Bölüm Başkanı Doç. Dr. Selda UCA'ya teşekkürlerimizi sunarız.

\section{KAYNAKÇA}

Adal, S. (2018). Yumurta Kabuğu Tozu Kullanılarak Mineral Madde Bakımından Zenginleştirilen Ekmeklerin Bazı Fiziksel ve Kimyasal Özelliklerinin Belirlenmesi. Manisa 
Celal Bayar Üniversitesi Fen Bilimleri Enstitüsü Gıda Mühendisliği Ana Bilim Dalı Yüksek Lisans Tezi, Manisa, Türkiye, 124 s.

Adıüzel, F., Kızılaslan, N. (2020). İstanbul İli Küçükçekmece İlçesinde Tüketicilerin Ambalajlı Ekmek Tüketim Tercihleri. Gariosmanpasa Bilimsel Arastirma Dergisi (GBAD), 3(2): 24-40, https://dergipark.org.tr/tr/pub/gbad/issue/573 $04 / 721427$.

Ahbap, B. Ö. (2014). Renklerin Pazarlama Üzerindeki Etkisi. İstanbul Kültür Üniversitesi, Sosyal Bilimler Enst. İşletme Ana Bilim Dalı, Yüksek Lisans Tezi, İstanbul, Türkiye, $123 \mathrm{~s}$.

Ahmad, B. S., Talou, T., Straumite, E., Sabovics, M., Kruma, Z., Saad, Z., Hijazi, A., Merah, O. (2018). Protein Bread Fortification with Cumin and Caraway Seeds and By-Product Flour. Foods, 7(3): 28, https://doi.org/10.3390/foods7030028.

Ahmadi-Dastgerdi, A., Gholami-Ahangaran, M., Saafizadeh, Z. (2019). Antibacterial And Antifungal Effect Of Achillea Millefolium Essential Oil During Shelf Life Of Mayonnaise. Food Sci Technol, 13(4): 12-20, https://doi.org/10.15673/fst.v13i4.1568.

Akgün, F. B. (2007). Ekşi Hamur Tozu Eldesi ve Ekmek Üretiminde Kullanılabilme Olanakları. Pamukkale Üniversitesi Fen Bilimleri Enstitüsü Gıda Mühendisliği Ana Bilim Dalı Yüksek Lisans Tezi, Denizli, Türkiye, $68 \mathrm{~s}$.

Aksoylu, Z., Savlak, N. Y., Yanğıç, C.., Çağınd1, Ö., Köse, E. (2014). Manisa İ Merkezinde Bireylerin Ekmek Çeşitlerini Tüketim Alıskkanlıklarının Belirlenmesi. GIDA 39(3): 147154, https://dergipark.org.tr/tr/pub/gida/ issue/ 6966/92857.

Annett, L.E., Spaner, D., Wismer, W.V. (2007). Sensory Profiles of Bread Made from Paired Samples of Organic and Conventionally Grown Wheat Grain. J Food Sci, 72(4): 254-260, doi: 10.1111/j.1750-3841.2007.00331.x.

Arslan Burnaz, N., Hendek Ertop, M., Karataş Ş. M. (2018). Tibbi ve Aromatik Bitkilerin Kullanımı ile Ekmeğin Fenolik Madde İçeriğinin Zenginleştirilmesi. GID A, 43(2): 240-249, https://doi.org/10.15237/gida.GD17098.
Aydın, F., Yıldız, Ş. (2011). Sivas İlinde Ekmek Tüketim Alışkanlıkları ve Tüketici Dinamiklerinin Belirlenmesi. Atatürk Üniv. Ziraat Fak. Derg., A 42 (2): 165-180.

Barış1k, D., Tavman Ş. (2018). Glütensiz Ekmek Formülasyonlarında Nohut Unu Kullanımının Ekmeğin Kalitesi Üzerine Etkisi. Akademik Gıda, 16(1): $33-41$, https://doi.org/10.24323/akademikgida. 415652 .

Benítez, V., Esteban, R. M., Moniz, E., Casado, N., Aguilera, Y. (2018). Breads fortified with wholegrain cereals and seeds as source of antioxidant dietary fibre and other bioactive compounds. J Cereal Sci, 82: 113-120, https://doi.org/10.1016/j.jcs.2018.06.001.

Bilgiçli, N. (2000). Melaslı Besin Ortamında Ekmek Mayası Üretim Paremetrelerinin Tespiti ve Sivı Mayanın Likid Ferment Sistemi ile Ekmek Yapımında Kullanılma İmkanları. Selçuk Üniversitesi Fen Bilimleri Enstitüsü, Gıda Mühendisliği Ana Bilim Dalı Yüksek Lisans Tezi, Konya, Türkiye, $46 \mathrm{~s}$.

Boyac1, B. B. (2008). Zenginleştirilmiş Unlardan Farklı Koşullarda Üretilen Ekmeklerin Bazı B Vitamini İçeriklerinin İncelenmesi. Hacettepe Üniversitesi Fen Bilimleri Enstitüsü Gıda Mühendisliği Ana Bilim Dalı Doktora Tezi, Ankara, Türkiye, 148 s.

Brahma, J., Narzary, D. (2015). Bioactive and Nutraceutical Compound Manipulation from the Leaves of Some Wild Edible Medicinal Plants in Chirang District of Assam, İndia. Am J Ethnomed, 2(6): 356-364.

Burnaz, N. A., Ertop, M.H. (2020). The Effect of Milk Powder Addition on the Properties of Bread Quality and Funcrionality. GID A, 45(2): 193-203

Ceyhun Sezgin, A., Ceylan, V., Yllmaz, A. (2019). Kültür Aktarımında Gastronomik Ögelerin Yeri: Anadolu'nun Farklı Yörelerinden İstanbul'a Göç Eden Aileler Üzerine Bir Araştırma. Eurasian, Acad Sci, Özel Sayı: 185-194.

Coşkun, F. B. (2012). Zenginleştirilmiş Kahvaltılı Tahıl Ürünlerinde Depolama Süresinin Bazı B Vitamini İçerikleri Üzerine 
Etkisinin İncelenmesi. Hacettepe Üniversitesi Fen Bilimler Enstitüsü Gıda Mühendisliği Ana Bilim Dalı Yüksek Lisans Tezi, Ankara, Türkiye, $96 \mathrm{~s}$.

Demir, M. K., Elgün, A., Argun, M. Ş. (2009). Sütçülük Yan Ürünlerinden Peynir Altı, Yay1k Altı ve Süzme Yoğurt Suları Katkılarının Bazı Ekmek Özelliklerin Etkileri Üzerinde Bir Araştırma. GID A, 34(2): 99-106, https://dergipark.org.tr/en/pub/gida/issue/ 684 5/91791.

Demir, M. K., Olcay, N. (2020). Ekmek Üretiminde Farklı Turunçgil Aldebolarının Kullanım İmkanları. KSÜ Tarm ve Doğa Dergisi, 23(6): 1545-1553, https://doi.org/10.18016/ ksutarimdoga.vi.730246.

Demirezer, Ö., Ersöz, T., Saraçoğlu, İ., Şener, B., Köroğlu, A., Yalçın, F. N. (2019). A'dan Z'ye Tıbbi Bitkiler. Hayykitap, İstanbul, Türkiye, 520 s. ISBN: 9786057674340.

Duran, M. Ö., Özçelik, S., Certel, M., Erbaş, M. (2004). Ticari Şartlarda Ekmek Üretiminde Patates ve Yulaf Unu Kullanımının Hamur ve Ekmek Özelliklerine Etkileri. GIDA, 29(2): 139147, https://dergipark.org.tr/en/pub/gida/ issue/6985/93080.

Durmuş, Y. (2019). Fındık Zarı ve Modifiye Nişasta İlavesinin Ekşi Hamur Reolojisi, Ekmek Kalitesi ve Sindirilebilirlik Üzerine Etkileri. Ondokuz May1s Üniversitesi Fen Bilimleri Enstitüsü Gıda Mühendisliği Ana Bilim Dalı Doktora Tezi, Samsun, Türkiye, 222s.

Dursun, S. (2006). Ekmek Zenginleştirmede Protein Kaynağı Olarak Balık Etinin Kullanımı. Pamukkale Üniversitesi Fen Bilimleri Enstitüsü Gıda Mühendisliği Ana Bilim Dalı Yüksek Lisans Tezi, Denizli, Türkiye, 99 s.

Edreva, A., Vitkova, A., Gesheva, E. (2019). Field-Cultivated Plants From Achillea Millefolium Group: Total Flavonoid Content, Antiradical And Antioxidant Activities In Stems And Leaves, And Ratio Of Plant Parts. Genet Plant Physiol, 9(1-2): 3-10.

Ekmekçi Bal, Z., Sayıll, M., Gözener, B. (2013). Tokat İli Merkez İlçede Ailelerin Ekmek
Tüketimleri Üzerine Bir Araştırma. Gažiosmanpaşa Üniversitesi Ziraat Fakültesi Dergisi, 30(1): 61-69, https://doi.org/10.13002/jafag186.

Elía, M. (2011). A Procedure for Sensory Evaluation of Bread: Protocol Developed by a Trained Panel. J Sens Stud, 26: 269-277, https://doi.org/10.1111/j.1745-

459X.2011.00342.x.

Erdemir, Z. Ş. (2015). Isıl İşlem Görmüş Bakla Ezme Tozunun Ekmek Yapımında Kullanımı ve Kalite Kriterleri Üzerine Etkisinin Belirlenmesi. Pamukkale Üniversitesi Fen Bilimleri Enstitüsü Gıda Mühendisliği Ana Bilim Dalı Yüksek Lisans Tezi, Denizli, Türkiye, $71 \mathrm{~s}$.

Giboreau, A., Dacremont, C., Egoroff, C., Guerrand, S., Urdapilleta, I., Candel, D., Dubois, D. (2007). Defining sensory descriptors: Towards writing guidelines based on terminology. Food Qual Prefer, 18: 265-274, https://doi.org/ 10.1016/j.foodqual.2005.12.003.

Göçmen, D. (2001). Ekşi Hamur ve Laktik Starter Kullanımının Ekmekte Aroma Oluşumu Üzerine Etkileri. GIDA, 26(1): 13-16, https://dergipark.org.tr/en/pub/gida/issue/ 691 $7 / 92407$.

Gül, V. (2014). Rize Yöresine Ait Tibbi ve

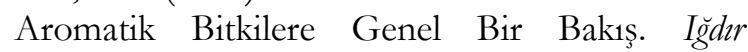
Üniversitesi Fen Bilimleri Enstitü Dergisi, 4(4): 97107, https://dergipark.org.tr/en/pub/jist/issue/ 7940/388682.

Ho, P. (2015). Statistical Methods and Tools for Analysing Sensory Food Texture. In: Modifying Food Texture, vol 2 - Sensory Analysis, Consumer Requirements and Preferences, Chen, J., Rosenthal, A. (Eds.) Woodhead Publishing, pp. 45-88.

Howyzeh, M. S., Aslani, S., Pooraskari, O. (2019). Essential Oil Profile of an Iranian Yarrow (Achillea millefolium). J Essent Oil Bear Plants, 33(2): 395-300, https://doi.org/10.1080/ 0972060X.2019.1586589.

ISO (International Organization for Standardization) 5492 (1992). Sensory analysis. Vocabulary.

ISO (International Organization for Standardization) 8586 (1993). Sensory analyses. 
General guidance for the selection, training and monitoring of assessors. Part 1: Selected assessors

ISO (International Organization for Standardization) 8589 (2007). Sensory analysis general guidance for the design of test rooms. Geneva, Switzerland: International Organization for Standardization.

İkikat Tümer, E., Aytop, Y., Yavuz, K. B. (2019). Ekmek İsraf Etme Durumunun ve İsrafta Etkili Olan Faktörlerin Belirlenmesi: Kahramanmaraș Kent Merkezi Örneği. Türk Tarm ve Doğa Bilimleri Dergisi, 6(3): 432-439, https://doi.org/10.30910/ turkjans.595223.

İlhan, E., Büyükizgi, A. N., Ermiş, E. (2020). Mavi-Yeşil Alg Spirulina platensis'in Buğday Ekmeğinde Kimyasal, Duyusal ve Antifungal Etkisi. Gida ve Yem Bilimi-Teknolojisi Dergisi, 24(2): 22-29, https://dergipark.org.tr/en/pub/ bursagida/issue/56608/788050.

Jaradat, N., Zaid, A. N., Hussein, F., Zaqzouq, M., Aljammal, H., Ayesh, O. (2017). Anti-Lipase Potential of the Organic and Aqueous Extracts of Ten Traditional Edible and Medicinal Plants in Palestine; a Comparison Study with Orlistat. Medicines, 4(4): 89, https://doi.org/10.3390/ medicines4040089.

Khoozani, A. A., Kebede, B., Birch, J., Bekhit, A. E.-D. A. (2020). The Effect of Bread Fortification with Whole Green Banana Flour on Its Physicochemical, Nutrieional and In Vitro Digestibility. Foods, 9(2): 152, https://doi.org/10.3390/foods9020152.

Kütük, D. (2010). Farklı Depolama Koşullarının Zenginleştirilmiş Makarnanın Vitamin İçeriği Üzerine Etkisinin İncelenmesi. Hacettepe Üniversitesi Fen Bilimleri Enstitüsü Gıda Mühendisliği Ana Bilim Dalı Yüksek Lisans Tezi, Ankara, Türkiye, $92 \mathrm{~s}$.

Mikulec, A., Kowalski, S., Makarewicz, M., Skoczylas, L., Tabaszewska, M. (2020). Cistus Extract as a Valuable Component for Enriching Wheat Bread. LWT - Food Sci Technol, 118: 108713, https://doi.org/10.1016/j.lwt.2019.108713.
Onoğlu, T. A., Elmac1, Y. (2019). Gidalarda Duyusal Değerlendirme. Sidaş Medya Ltd. Şti., Türkiye, 135 s. ISBN: 9789944566087.

Ödeş, N. (2018). Farklı Oranlarda Üzüm Çekirdeği İçeren Ekmeklerin Ekmek Verimi ve Kalitesini Glikoz Oksidaz ile İyileştirme İmkanlarının Araştırılması. Süleyman Demirel Üniversitesi Fen Bilimleri Enstitüsü Gıda Mühendisliği Ana Bilim Dalı Yüksek Lisans Tezi, Isparta, Türkiye, $102 \mathrm{~s}$.

Özdemir, M., Arslanoğlu, Ş. F., Sert, S. (2020). Geçmişten Günümüze Karahindiba (Taraxacum officinale) Bitkisi. 3. Uluslararas1 19 Mayıs Yenilikçi Bilimsel Yaklaşım Kongresi, 16-19 Mayıs 2020, Samsun, Türkiye, 81-89 s.

Özkan Özdemir, P., Fettahlıoğlu, S., Topoyan, M. (2009). Fonksiyonel Gıda Ürünlerine Yönelik Tüketici Tutumlarını Belirleme Üzerine Bir Araştırma. Ege Akademik Bakış, 9(4): 1079-1099.

Pala, A. (2012). Farklı Yöntemlerle Kurutularak Elde Edilen Boza Tozunun Hamur Reolojik ve Ekmek Kalitesi Üzerine Etkisi. Pamukkale Üniversitesi Fen Bilimleri Enstitüsü Gıda Mühendisliği Ana Bilim Dalı Yüksek Lisans Tezi, Pamukkale, Türkiye, 70 s.

Penso, G. (1980). The Role of WHO in the Selection and Characterization of Medicinal Plants (Vegetable Drugs). Journal Ethnopharmacol, 2(2): 183-188, https://doi.org/10.1016/03788741(80)90013-6.

Ranum, P. M. (2000). Cereal Enrichment and Nutrient Labeling. In Handbook of Cereal Science and Technology. CRC Press, 790 s. ISBN: 9780824782948

Robles-Ramírez, M.D., Ortega-Robles, E., Monterrubio-López, R., Mora-Escobedo, R., Beltrán-Orozco, M.C. (2020). Barley Bread with Improved Sensory and Antioxidant Properties. International J Gastron Food Sci, 22: 100279 , https://doi.org/10.1016/j.ijgfs.2020.100279.

Shiv, B., Edell, A. J., Payne, W. J. (1997). Factors affecting the impact of negatively and positively framed ad messages. J Consumer Res, 24: 285-294, https://doi.org/10.1086/209510. 
Shrivastava, C., Chakraborty, S. (2018). Bread from Wheat Flour Partially Replaced by Fermented Chickpea Flour: Optimizing the Formulation and Fuzzy Analysis of Sensory Data. LWT-Food Sci Technol, 90:215223, https://doi.org/10.1016/j.lwt.2017.12.019 .

Tanık, O. (2006). Ekmek Üretiminde Kalite Uygulamalar1 ve Müşteri Memnuniyet Dinamiklerinin Belirlenmesi. Trakya Üniversitesi Fen Bilimleri Enstitüsü Tarım Ekonomisi Ana Bilim Dalı Yüksek Lisans Tezi, Tekirdağ, Türkiye, $85 \mathrm{~s}$.

TGK, 2016. Gıda ve Kontrol Genel Müdürlüğü, Türk Gıda Kodeksi Gidalarda Kullanilabilecek Bitkiler ve Bitkisel Preparatlar Tebliği, Bölüm-2: Bitki Listeleri ve Bitkilerin, Bitki Kısımlarının ve Bitkisel Preparatların Gıdalarda Kullanımı, Ek-5, 08.02.2016. https://www.tarimorman.gov.tr/ GKGM/Duyuru/172/Turk-Gida-KodeksiGidalarda-Kullanilabilecek

Tiong, S. A., Chandra-Hioe, M. V., Acrot, J. (2015). Thiamin Fortification of Bread-Making Flour: Retention in Bread and Levels in Australian Commercial Fortifies Bread Varieties. J Food Compos Anal, 38: 27-31, https://doi.org/ 10.1016/j.jfca.2014.11.003.

TMO (2013). 2013 Yılı Ekmek İsrafinı Önleme Kampanyası ve Sonuçları. https://www.tmo.gov.tr/Upload/Document/K ampanya/TanitimKitabi.pdf (Accessed: 23.03.2021)

TUBER 2019. Türkiye Beslenme Rehberi (TUBER) https://hsgm.saglik.gov.tr/depo/ birimler/saglikli-beslenme-hareketli-hayat db/Turkiye_Beslenme_Rehberi_TUBER_18_04 _2019.pdf (Accessed: 24.03.2021)

Tuluk, K. (2017). Farklı Oranlarda Lupin Unu Kullanılarak Üretilen Beyaz Ekmek ve Tam Buğday Ekmeğinin Bazı Kalite Özelliklerinin Belirlenmesi. Ege Üniversitesi Fen Bilimleri Enstitüsü Gıda Mühendisliği Ana Bilim Dalı Yüksek Lisans Tezi, İzmir, Türkiye, $171 \mathrm{~s}$.
Turan, Ş. (2014). Ülkemizde Yaygın Olarak Kullanılan Bazı Tibbi Bitkilerin Yapraklarında Ağır Metal ve Mineral Besin Element İçeriklerinin Tayini. Marmara Üniversitesi Gen Bilimleri Enstitüsü Kimya Ana Bilim Dalı Yüksek Lisans Tezi, İstanbul, Türkiye, $265 \mathrm{~s}$.

Uzundumlu, A. S., Yıldırım, B. Z., Kurtoğlu, S. (2018). Erzurum İli'nde Ekmek Tüketimini Etkileyen Faktörlerin Belirlenmesi. J Acad Soc Sci Stud, 6(77): 17-31, http://dx.doi.org/10.16992/ ASOS.14023.

Varlı, M., Hanc1, H., Kalafat, G. (2020). Tibbi ve Aromatik Bitkilerin Üretim Potansiyeli ve Biyoyararll1ı̆̆1. Res J Biomed Biotechnol, 1: 24-32, https://dergipark.org.tr/en/pub/rjbb/issue/563 12/710963.

Verhagen, H., Alonso-Andicoberry, C., Assunção, R., Cavaliere, F., et al. (2021). Riskbenefit in food safety and nutrition - Outcome of the 2019 Parma Summer School. Food Res Int, 141: 110073, https://doi.org/10.1016/j.foodres. 2020.110073 .

Vindras-Fouillet, C., Ranke, O., Anglade, J., Taupier-Letage, B., Véronique, C., Goldringer, I. (2014). Sensory Analyses and Nutritional Qualities of Hand-Made Breads with Organic Grown Wheat Bread Populations. Food Nutr Sci, doi: 10.4236/fns.2014.519199

Yarpuz, D. (2011). Glutensiz Ekmek Üretimi Üzerine Araştırmalar. Selçuk Üniversitesi Fen Bilimleri Enstitüsü Gıda Mühendisliği Ana Bilim Dalı Yüksek Lisans Tezi, Konya, Türkiye, 113 s.

Yiğit, A. H., Doğan, İ. S. (2010). Ağr1 İlindeki Ekmek Fırınlarının Bazı Özelliklerinin Değerlendirilmesi Üzerine Bir Anket Çalışması. YYÜ Tarm Bilimleri Dergisi, 20(2): 75-87, https://dergipark.org.tr/tr/pub/yyutbd/issue/2 $1983 / 236037$. 